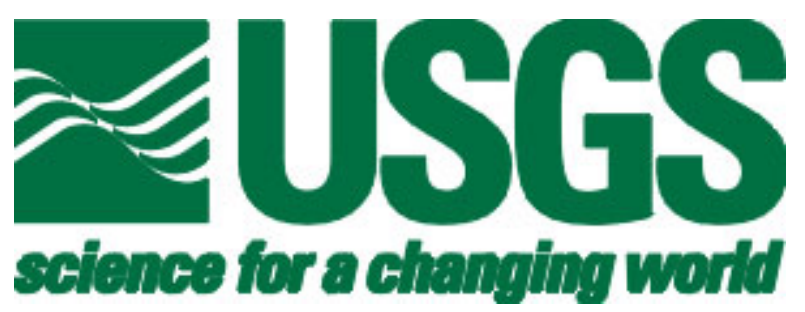

\title{
Assessment method for epithermal gold deposits in northeast Washington State using weights-of-evidence GIS modeling
}

By D. E. Boleneus ${ }^{1}$, G. L. Raines ${ }^{2}$, J. D. Causey ${ }^{1}$, A. A. Bookstrom ${ }^{1}$, T. P. Frost ${ }^{1}$, and P.C. Hyndman $^{1}$

Open-File Report 01-501

2001

Prepared in cooperation with the USDA Forest Service, Pacific Northwest Region, Okanogan and Colville National Forests

This report is preliminary and has not been reviewed for conformity with U.S. Geological Survey editorial standards. Any use of trade, product, or firm names is for descriptive purposes only and does not imply endorsement by the U.S. Government.

Although these programs have been used by the US Geological Survey, no warranty, expressed or implied, is made by the USGS as to the accuracy and functioning of the programs and related program material, nor shall the fact of distribution constitute any such warranty, and no responsibility is assumed by the USGS in connection therewith.

Approved by the Director December 31, 2001

\section{U. S. DEPARTMENT OF THE INTERIOR \\ U. S. GEOLOGICAL SURVEY}

\footnotetext{
${ }^{1}$ U.S. Geological Survey, West 904 Riverside Avenue \#202, Spokane, Washington 99201

${ }^{2}$ U.S. Geological Survey, Mackay School of Mines, MS 176, University of Nevada, Reno, Nevada 89557-0047
} 


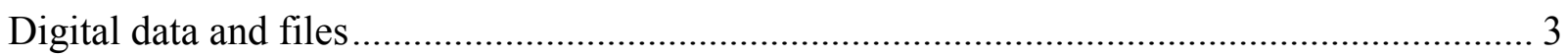

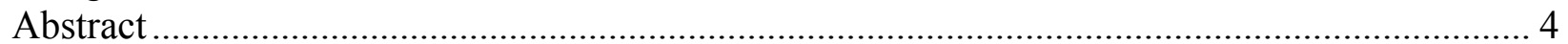

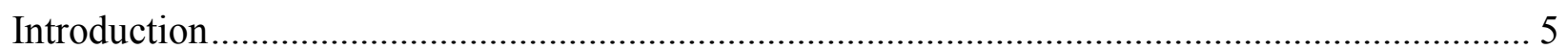

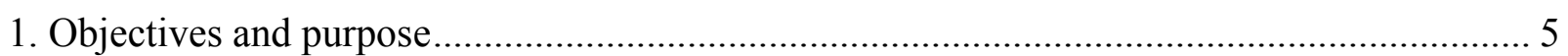

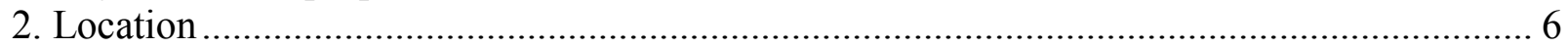

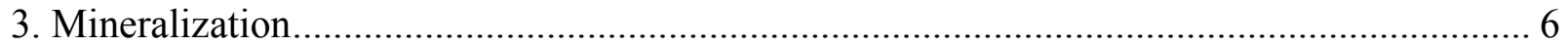

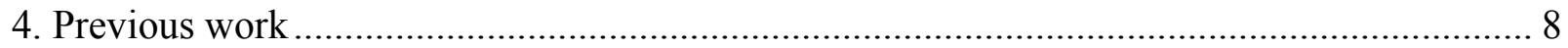

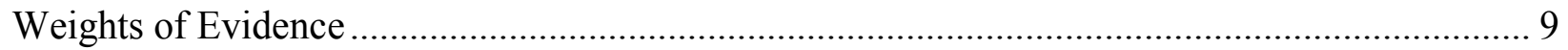

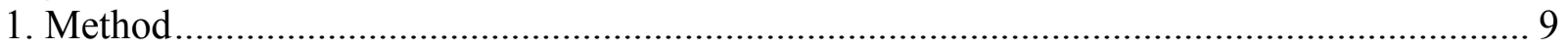

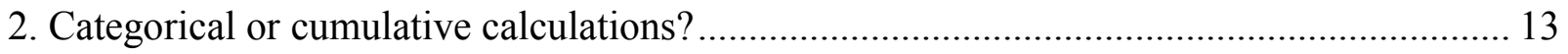

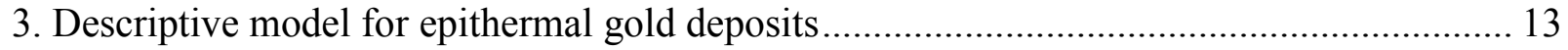

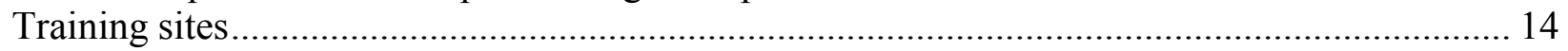

Analysis of geologic patterns for epithermal model ......................................................... 15

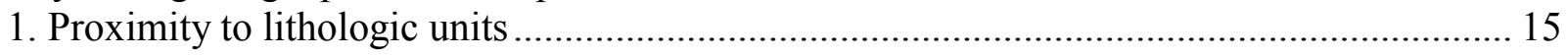

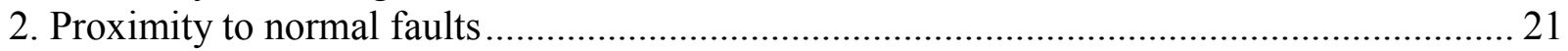

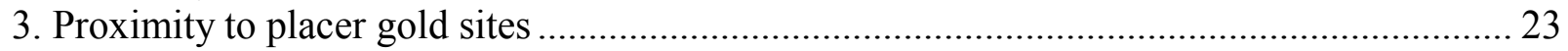

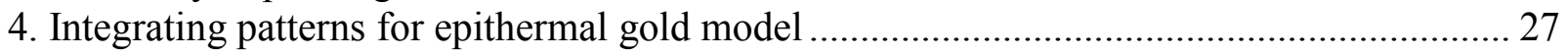

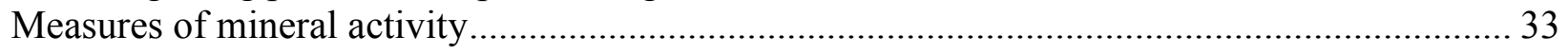

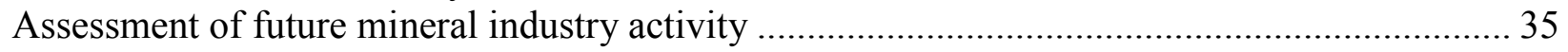

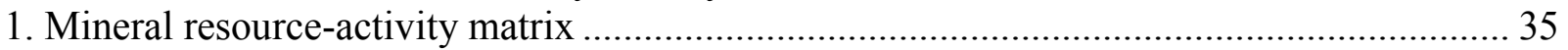

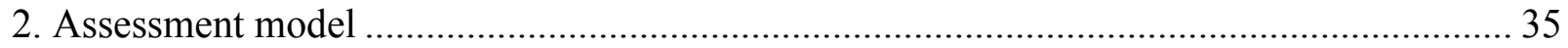

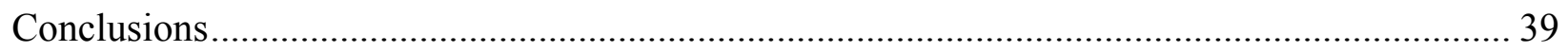

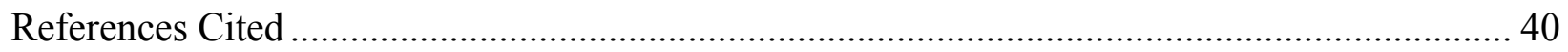

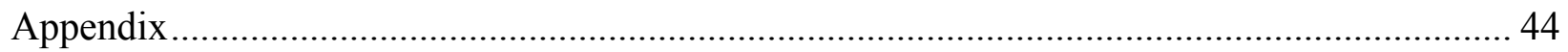

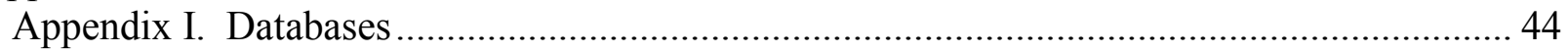

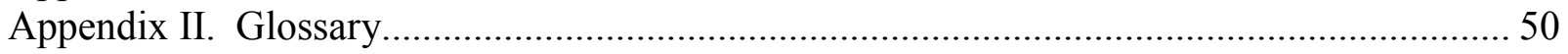

\section{Figures}

Figure 1. Location map showing training sites and significant epithermal gold deposits in northeast Washington.................................................................................... 7

Figure 2. Venn diagram showing overlay of geologic and geochemical themes used in weights-

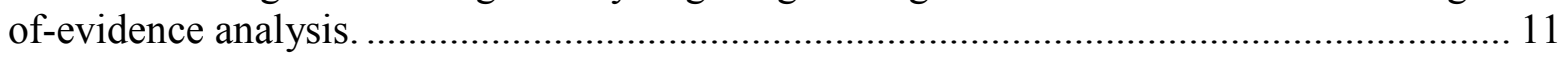

Figure 3. Flow diagram describing mineral assessment procedure for epithermal gold. ........... 12

Figure 4. Lithologic units pattern and normal faults pattern maps..................................... 18

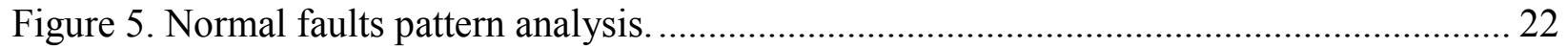

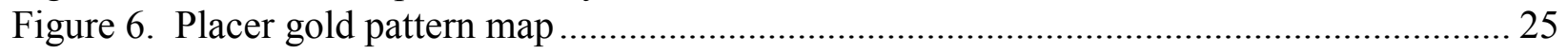

Figure 7. Placer gold pattern analysis. ........................................................................ 26

Figure 8. Probability results for epithermal gold deposit model. .......................................... 31

Figure 9. Map of epithermal gold deposit model showing favorable, permissive, and non-

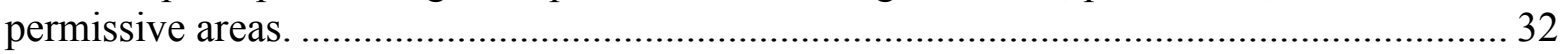

Figure 10. Historic, current, and consistent mining claims activity. ................................... 34

Figure 11. Resource model-activity model matrix. ..................................................... 36

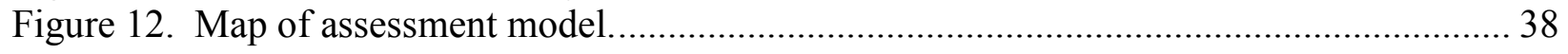




\section{Tables}

Table 1. Themes investigated for epithermal gold deposit model. ..................................... 16

Table 2. Proximity analysis for lithologic map units. ......................................................... 17

Table 3. Proximity analysis for eight selected lithologic units. ........................................... 20

Table 4. Number of normal fault segments whose orientations range from $345^{\circ}$ to $30^{\circ}$.......... 21

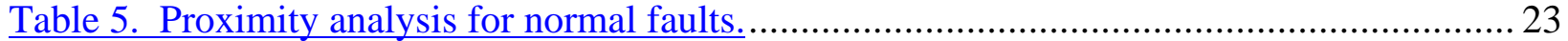

Table 6. Proximity analysis for placer gold sites. ............................................................. 27

Table 7. Weights-of-evidence predictor theme data of epithermal gold model........................ 28

Table 8. Unique conditions data for epithermal gold deposit model. ................................... 30

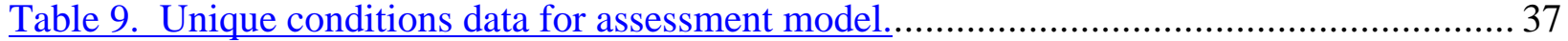

\section{Digital data and files}

Text and data from this report can be found on the internet at the USGS website:

http://geopubs.wr.usgs.gov/open-file/of01-501

Text and other files accompanying this report are listed below:

[txt -- ascii text document, PDF -- Adobe Acrobat Portable Document Format, JPEG -- raster image compression formats]

\begin{tabular}{l|l|l|l|l}
\hline \multicolumn{1}{c|}{ Name } & \multicolumn{1}{c|}{ Folder } & \multicolumn{1}{c|}{ Type } & \multicolumn{1}{c}{ Description } & Size, MB \\
\hline 1_README.txt & Epithermal_OFR & ascii & readme & 0.07 \\
\hline OF01-501.jpg & Epithermal_OFR/Report & PDF & Report text and tables & 0.91 \\
\hline $\begin{array}{l}\text { fig1, fig4ab, fig6, fig9, fig10, } \\
\text { fig12 }\end{array}$ & jpg & JPEG & Figures 1, 4, 6, 9, 10, 12 & 2.22 \\
\hline $\begin{array}{l}\text { fig1, fig4ab, fig6, fig9, fig10, } \\
\text { fig12 }\end{array}$ & pdf & PDF & $\begin{array}{l}\text { Figures 1, 4, 6, 9, 10, 12 } \\
\text { dpi) }\end{array}$ & 3.08 \\
\hline
\end{tabular}




\begin{abstract}
The weights-of-evidence analysis, a quantitative mineral resource mapping tool, is used to delineate favorable areas for epithermal gold deposits and to predict future exploration activity of the mineral industry for similar deposits in a four-county area $(222 \times 277 \mathrm{~km})$, including the Okanogan and Colville National Forests of northeastern Washington. Modeling is applied in six steps: (1) building a spatial digital database, (2) extracting predictive evidence for a particular deposit, based on an exploration model, (3) calculating relative weights for each predictive map, (4) combining the geologic evidence maps to predict the location of undiscovered mineral resources and (5) measuring the intensity of recent exploration activity by use of mining claims on federal lands, and (6) combining mineral resource and exploration activity into an assessment model of future mining activity.

The analysis is accomplished on a personal computer using ArcView GIS platform with Spatial Analyst and Weights-of-Evidence software. In accord with the descriptive model for epithermal gold deposits, digital geologic evidential themes assembled include lithologic map units, thrust faults, normal faults, and igneous dikes. Similarly, geochemical evidential themes include placer gold deposits and gold and silver analyses from stream sediment (silt) samples from National Forest lands. Fifty mines, prospects, or occurrences of epithermal gold deposits, the training set, define the appropriate areally-associated terrane. The areal (or spatial) correlation of each evidential theme with the training set yield predictor theme maps for lithology, placer sites and normal faults. The weights-of-evidence analysis disqualified the thrust fault, dike, and gold and silver silt analyses evidential themes because they lacked spatial correlation with the training set. The decision to accept or reject evidential themes as predictors is assisted by considering probabilistic data consisting of weights and contrast values calculated for themes according to areal correlation with the training sites. Predictor themes having acceptable weights and contrast values are combined into a preliminary model to predict the locations of undiscovered epithermal gold deposits. This model facilitates ranking of tracts as non-permissive, permissive or favorable categories based on exclusionary, passive, and active criteria through evaluation of probabilistic data provided by interaction of predictor themes. The method is very similar to the visual inspection method of drawing conclusions from anomalies on a manually overlain system of maps. This method serves as a model for future mineral assessment procedures because of its objective nature.

To develop a model to predict future exploration activity, the locations of lode mining claims were summarized for 1980, 1985, 1990, and 1996. Land parcels containing historic claims were identified either as those with mining claims present in 1980 or valid claims present in 1985. Current claim parcels were identified as those containing valid lode claims in either 1990 or 1996. A consistent parcel contains both historic and current claims.

The epithermal gold and mining claim activity models were combined into an assessment (or mineral resource-activity) model to assist in land use decisions by providing a prediction of mineral exploration activity on federal land in the next decade. Ranks in the assessment model are: (1) no activity, (2) low activity, (3) low to moderate activity, (4) moderate activity and (5) high activity.
\end{abstract}




\section{INTRODUCTION}

\section{Objectives and purpose}

This report presents the results of an assessment of the relative favorability and anticipated future minerals development activity in northeastern Washington for gold-silverbearing epithermal mineral deposits. The two-part assessment is accomplished using weights-ofevidence in a geographic information system (GIS). The weights-of-evidence analysis is a data driven GIS tool adapted from the medical diagnostics field to mineral resource assessment (Kemp and others, 1999).

The first component of the assessment is based on the physical evidence (geology, geochemistry, geophysics and so on) that indicates mineralizing processes may have occurred in an area. In this case, the epithermal gold deposit model incorporates geological and geochemical data in assessing the probability of occurrence of undiscovered gold and silver deposits. A procedure is introduced in the construction of this model using the probability results from the weights-of-evidence analysis as a decision-making tool. This tool is used to establish the relative favorability of tracts for the occurrence of mineral deposits using the terms non-permissive, permissive, and favorable tracts. The exploration activity model incorporates mineral-industry exploration activity using past and current mining claims data, industry reports, publications, and other public-domain resources as a predictor of the minerals exploration and development activity which may be expected in a given area. The significance of the two-part approach to assessment is that it combines the results of both the undiscovered mineral resource and mining claim activity.

This study was performed to assist the United States Forest Service in planning for land uses. The study area includes much of the Okanogan and Colville National Forests. Six related geologic reports provided supporting digital data for this analysis can be downloaded from the USGS website. The first report presents the geologic raster data (Boleneus and Causey, 2000)-lithology, faults, folds, and igneous dikes themes--used extensively in the weights-of-evidence analysis. The report documents the study area's seamless digital geologic map constructed from six, 100:000-scale geologic maps and includes ArcView shapefiles. Various geochemical themes were also prepared. Analytical data for gold, silver, lead, zinc, copper, molybdenum, tungsten, and uranium were digitally compiled for 3,927 rock and stream sediment (silt) samples collected by R.A Grant (unpublished data) from the Okanogan and Colville National Forests (Boleneus and Chase, 1999). Four other reports present geological and mineral activity databases used. The first includes the training set of 50 epithermal deposits and the 67 gold placer sites (Boleneus, 1999a). Hyndman and Campbell (1999) prepared the digital database of mining claims used for mineral industry exploration activity data. Two other reports document mineral industry exploration activity data in Washington examined during the analysis. These include mineral permits issued by the Colville, Kaniksu, Okanogan, and Wenatchee National Forests (Boleneus, 1999 b) and a 13-year summary of mineral industry project activity in Washington (Boleneus and Derkey, 2000).

Also, the method serves as a model for future mineral assessments because of its objective nature and strict application of procedures of the weights-of-evidence analysis. Using the information and procedure applied here--epithermal deposit model, data, software, and methods--duplication of these results by others is assured. 
Analysis was performed on a personal computer using ArcView v. $3.1^{3}$, Spatial Analyst v. 1.0 and Weights-of-Evidence (Kemp and others, 1999) software. The assessment method requires that all data be analyzed in digital form. At least 100 person-days were expended to prepare the data before the analysis. The authors accomplished the analysis in a committee setting during three days.

\section{Location}

The study encompasses a 222-km x 277-km area bounded by Idaho on the east and Canada on the north. It includes all of Pend Oreille County and most of Stevens, Ferry, and Okanogan counties (lat 48-49 $\mathrm{N}$ and long117-120 E). The area occupies six, 1:100,000-scale U.S.G.S. quadrangles (Omak, Oroville, Colville, Chewelah, Republic, and Nespelem) in Washington State (fig. 1).

Exploration for gold has been concentrated around operating mines in Ferry and adjacent counties, including epithermal (or hot spring) gold deposits at Republic, Kettle, K-2 and Orient.

The report, in particular, addresses about one-half of the study area, or $23,600 \mathrm{~km}^{2}$ that contains Eocene volcanogenic rocks that host the deposits. Epithermal gold deposits are, for the most part, restricted to those Eocene volcanogenic and sedimentary rocks contained with the Republic Graben, the largest of four fault-bounded extensional troughs (Full and Grantham, 1968; Fifarek, Devlin, and Tschauder, 1996). This graben occurs between two pre-Eocene-age core complexes, the Okanogan and Kettle gneiss domes, consisting of meta-igneous, metasedimentary, and meta-volcanic rocks whose protoliths range in age from Devonian to Cretaceous (Fox, 1994; Box, 1994).

\section{Mineralization}

Epithermal gold deposits in northeast Washington are described by several authors (Full and Grantham, 1968; Tschauder, 1989; Fifarek, Devlin, and Tschauder, 1996; and Rasmussen and Gelber (written communication, 2000, 2001). Deposits are formed in a near-surface environment by deposition of gold and silver, in quartz-pyrite-clay-carbonate (+/- calcite, marcasite, ankerite, illite, kaolinite, and alunite) veins in a hot-spring environment. Deposits occur within a graben-filling Eocene pyroclastic, fluvial, and lacustrine succession consisting of O’Brien Creek, Sanpoil Volcanics, and Klondike Mountain formations. These Eocene successions occur within each of at least four grabens developed during the later stages of emplacement of the Kettle and Okanogan gneiss domes.

The Knob Hill and Golden Promise deposits (collectively, the Hecla Mining Co.

"Republic" operation) of the Republic district are the most notable and closed in 1995 after 100 years of activity. The Republic operation was located about $2 \mathrm{~km}$ northwest of the city of Republic, Washington. Golden Promise is located about $1.7 \mathrm{~km}$ southeast of Knob Hill. The Kettle and K-2 deposits had similar origins to the deposits at Republic and are located $25 \mathrm{~km}$ to the north-northeast. The Knob Hill mine was developed from a decline shaft but more recently, the K-2 and Golden Promise deposits were developed from decline or incline ramps and mined by cut-and-fill mine methods.

\footnotetext{
${ }^{3}$ ArcView and Spatial Analyst are software products of Environmental Systems Research Institute (ESRI) Inc., Weights-of-evidence software is a product of Geological Survey of Canada
} 


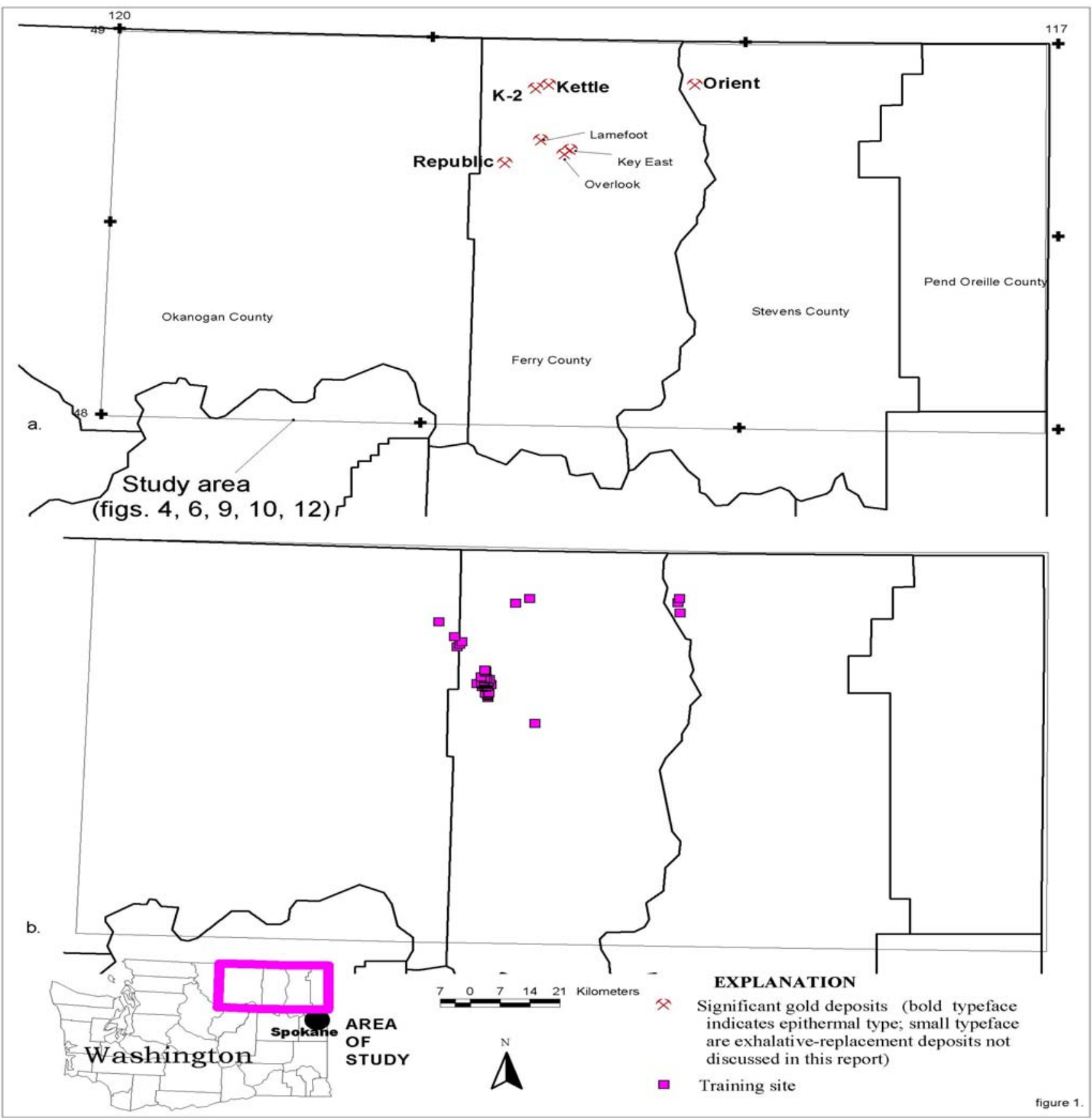

Figure 1. Location map showing training sites and significant epithermal gold deposits in northeast Washington.

(a) Significant epithermal gold deposits are Orient, Kettle, K-2, and Republic (Knob Hill). Other nearby gold deposits, the Lamefoot, Key East, and Overlook are exhalative-replacement gold deposits and are not considered in this report, but accounted for approximately 1 million troy ounces of gold production through 1997. (b) Fifty training sites are shown on the map. Training sites are locations of gold mines, prospects, or occurrences of epithermal origin. About one-half of the training sites have recorded gold production. See text for explanation of training sites. 
The gold deposits occur within the Sanpoil Volcanics up to $5 \mathrm{~km}$ eastward of the NNEtrending Bacon Creek Fault. The Bacon Creek Fault forms the west flank of the Republic graben, and numerous lesser NNE and NW-trending en echelon faults host gold-silver-bearing veins formed as a result of dextral-shearing adjustments in the Republic graben. Deposits occur entirely within the Sanpoil Volcanics and terminate (sometimes at sinter deposits) near the unconformity with the overlying Klondike Mountain Formation. The Sanpoil Volcanics consists of andesite and dacite lavas, epiclastic and pyroclastic rocks, conglomerate, and hornblende andesite porphyry flows. Free gold, gold selenides, and silver sulfosalts occur in conduits, vents and eruption ejecta of a Golden Promise hot springs system (Fifarek, Devlin, and Tschauder, 1996). Golden Promise vent breccias contain near-vertical, anastomizing zones of disseminated and stringer ore flanked by low grade gold in sinter at higher level. Sinter gold zones occur near the top of the Sanpoil Volcanics while the deeper, higher grade veins are characterized by breccia and colloform quartz textures in faults and fault breccia zones.

At Republic, the gold-silver-bearing veins consist of colloform and brecciated quartz where quartz, calcite, and sulfosalt minerals resulted from hot spring activity. Clays include kaolinite and alunite. Coarse, free gold is common. Ag-Au ratio is 5:1. At K-2, the gold-silverbearing, bladed latticework quartz and brecciated quartz predominates over colloform quartz textures. Also at K-2, little free gold exists and clays consist of illite and kaolinite. Sinter zones and sulfosalts are absent, ankerite predominates over calcite, and the Ag-Au ratio is 1:1

(Rasmussen and Gelber, written communication, 2000). The Kettle deposit is very similar to the Golden Promise deposit in both morphology and mineralogy (Rasmussen, written communication, 2000). These are identical to the well-known model for epithermal hot spring gold deposits presented by Buchanan (1981) for deposits of the southwest U.S.

\section{Production}

The principal mining district in the map area is the Republic Mining District. The first claims were staked here in 1896 and by 1901 two mills were operating. The first was a custom mill at the town of Republic, Washington and another, at the Mountain Lion mine, about $3 \mathrm{~km}$ northwest of Republic (Landes and others, 1902). About ten mines continuously operated in early history of the district. By 1912, the district had produced nearly $\$ 5,000,000$ in gold and silver. In 1936, owners of the Knob Hill Mine built a mill at the site of principal activity located about $2 \mathrm{~km}$ north of the town (Full and Grantham, 1968). Later known as the Republic mine, this property operated nearly continuously by Knob Hill Mines Inc., then by Day Mines Inc. and later by Hecla Mining Co. until closing in 1995. Historically, through 1997, the region has produced at least 3 million troy ounces (93 tonnes) gold and 17 million troy ounces (550 tonnes) silver from all deposits of epithermal origin (Fifarek, Devlin, and Tschauder, 1996). Echo Bay Mines, Inc. operated the Kettle mine for a short time before its reserve became exhausted and now operates the K-2 mine, the only active gold mine in the state.

\section{Previous work}

Use of the weights-of-evidence as an assessment method as applied to mineral deposits is a recent innovation. Bonham-Carter (1994) presents an in-depth explanation of the weights-ofevidence analysis and other GIS methods in geology and Wright and Bonham-Carter (1996) 
applied the method to search for areas likely to contain massive sulfide deposits in greenstone terrenes of Manitoba, Canada. Weights-of-evidence analysis has been used to predict favorable areas for vein gold deposits in Canada (Bonham-Carter, Agterberg, and Wright, 1988), for Carlin and epithermal gold deposits in Nevada (Mihalasky, 1999), and epithermal deposits in the Great Basin of the western United States (Raines, 1999). Explanation of the software operations of weights-of-evidence method followed in this report is available in the user guide (Kemp and others, 1999) and Raines, Bonham-Carter, and Kemp (2000) present an overview of the method.

\section{WEIGHTS OF EVIDENCE}

\section{Method}

The process used in weights-of-evidence modeling essentially is a quantitative version of the inspection method of overlaying several different map themes to identify areas where mineralization may be present (fig. 2). In the inspection method, the larger the number and magnitude of appropriate overlapping anomalies in data maps such as geochemistry, geology, or others, the greater the qualitative indication that mineralization may be present. In weights-ofevidence modeling, the importance of theme layers in delineating areas with potential for deposits is determined mathematically by how it compares with the areal distribution of the training set. When several themes are combined, the areas with the greatest coincidence of weights produce the greatest probability of occurrence of undiscovered mineralization.

Briefly, weights-of-evidence analysis is a map-correlation and map-integration process that is applied by formulating mathematical odds for (and against) and combining this evidence in support a hypothesis. In this report evidence consists of various evidence themes (see evidential themes, in Glossary) of exploration data, and the hypothesis is "this location is favorable for occurrence of deposit type ' $\mathrm{X}$ '". The odds of this association between the training set and each exploration theme (data) are measured and expressed as "weights", defined as the natural log of the odds. The Glossary gives an example of a weights and contrast calculation. Kemp and others (1999) and Bonham-Carter (1994) give a detailed treatment.

The weights-of-evidence analysis of epithermal gold deposits is applied here in two parts. First, the analysis assists in determining the limits for favorable, permissive, and non-permissive areas that may be used in exploring for undiscovered epithermal gold deposits. Second, a mining claim activity is derived and this, in turn, is combined with the epithermal gold model to create the assessment model. The assessment describes the probability of both the undiscovered mineral resource for gold and the mining claim activity. The preparation and analysis steps followed in this report are shown in a flow diagram (fig. 3) and briefly outlined below.

The procedure followed in applying a weights-of-evidence analysis in the first part of the two-part approach is carried out in five steps, as follows: (1) selection of a descriptive model; (2) selection of a training set; (3) selection of exploration (evidence) themes based on the descriptive model; (4) testing of the exploration themes to qualify them as viable (predictor) themes; and (5) consolidating the themes into a useful resource prediction model. The descriptive model used here is the mineral deposit model for epithermal (hot spring) gold deposits (Full and Grantham, 1968; Berger, 1986; Fifarek and others, 1996; M. Rasmussen and C. Gelber, written communication, 2000). These authors describe the geological setting and various characteristics of epithermal veins. Characteristics set out in the mineral deposit model are closely followed in selecting the training sites and evidence (or exploration) themes in the analysis. The training set consists of gold-silver mines (or non-producing prospects) of inferred epithermal origin. The 
location and characteristics of these mines or prospects were assembled from published sources such as U.S. Geological Survey' MRDS (USGS, 2000) or MAS/MILS (USBM, 1995) databases. In step 3, the evidence themes were assembled from several geological, geochemical, and other databases that describe aspects of the mineral deposit model in the study area. Evidence themes assembled include a digital geological map (Boleneus and Causey, 2000) containing lithologic units, dikes, folds, and faults and digital geochemical themes consisting of placer gold mines (Boleneus, 1999a) and gold-silver stream silt analysis (Boleneus and Chase, 1999). The geological map was manually compiled at a scale of 1:100,000 by the Washington Department of Natural Resources (Wash. DNR) in the 1980's-1990's and converted into digital form. Geological data (lithology, faults, dikes) defined by polygons or lines were prepared as ArcView shapefiles from Arc/Info data supplied by Wash. DNR. Thrust faults and normal faults themes were from a larger set of faults data. Sources of the placer gold mine sites were the USGS MRDS and USBM MAS/MILS. Mine site, training site, and geochemical themes were prepared as point-type database files. Using gold and silver geochemistry (Boleneus and Chase, 1999) contour maps were interpolated from point-type data using Spatial Analyst software in conjunction with the ArcView GIS platform software. Shapefiles and point databases were converted to grid format and then a series of buffer bands $(25 \mathrm{~m}$ up to $1000 \mathrm{~m}$ in width, as appropriate) were digitally constructed around the line, polygon, and point themes prior to the analysis. As many as 30 buffer bands were constructed with a radius ranging up to $30,000 \mathrm{~m}$ outboard from the lines or polygons (as appropriate).

In step 4, the testing process consisted of digitally comparing the areal (or spatial) distribution of training set and evidence themes. Testing produced weights, contrast, and other statistical values calculated for each of the seven comparisons (lithologic units, normal faults, thrust faults, dikes, placer sites, stream silt gold, and stream silt silver). The weights (positive weight $\mathrm{W}+$, negative weight, $\mathrm{W}-$-) express the degree of spatial association between the training set and the evidence theme. The contrast value is merely the difference between the positive weight value and the negative weight value. The contrast value is the basis for accepting (or rejecting) the evidence themes as predictor themes. It evaluates the significance of each buffer band, that is, the level of area (spatial) correlation between exploration theme " $\mathrm{X}$ " and the training set. In step 5, the predictor themes are consolidated into an epithermal gold deposit model by addition of values at each grid cell. The statistical significance of the contrast can be assessed to decide that the observed contrast is not due to a random event. For this study a confidence of approximately $98 \%$ was required to define a significant contrast.

A procedure is introduced that uses the weights-of-evidence results as a decision-making tool to establish relative favorability (and unfavorability) of tracts for the occurrence of mineral deposits. In this report, favorable, permissive, and non-permissive tracts (areas) are defined by the degree of overlap of predictor themes in the epithermal gold deposit model. This concept of geological favorability of tracts is not a part of the weights-of-evidence procedure. The concept (Singer, 1993) expresses the probabilistic data of this analysis in a geological context (favorable, permissive, non-permissive) applicable to mineral deposits.

In the second part of the two-part approach, the objective is to combine the epithermal gold deposit model with the mining claim activity information to create the assessment model. The steps are: (1) obtain mining claim activity data for the years of 1980, 1985, 1990, and 1996, (2) create a matrix to combine the mining claim activity and epithermal gold model, and (3) derive an assessment model by applying this matrix. The second part uses ArcView and Spatial Analyst software but is not a weights-of-evidence analysis. 


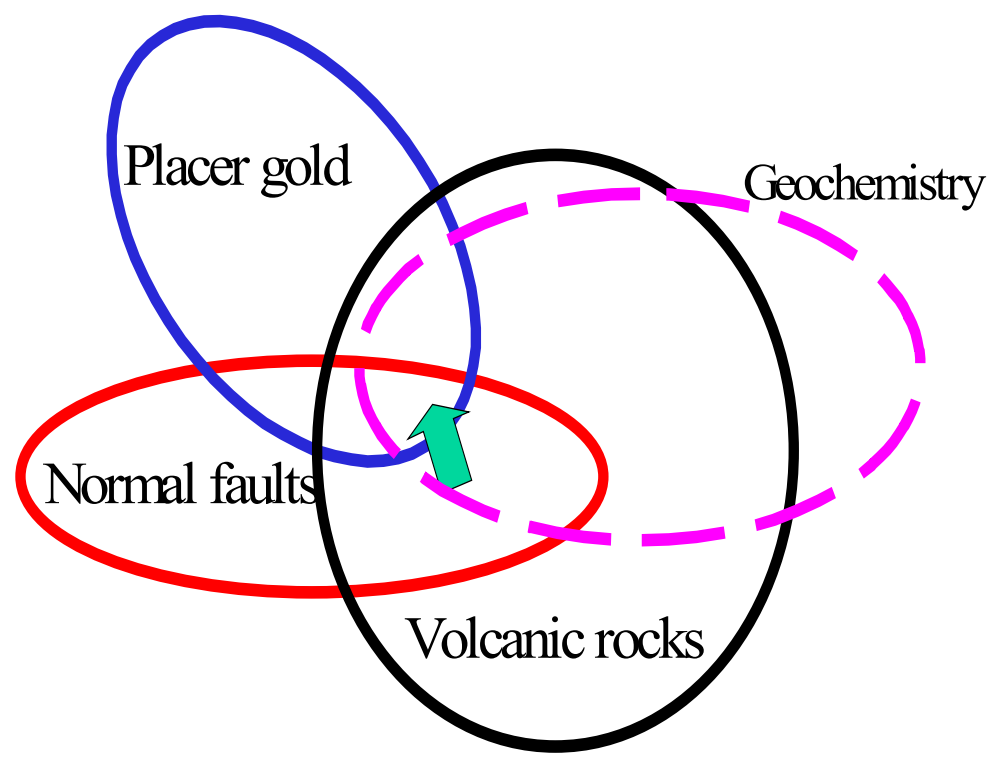

5

Figure 2. Venn diagram showing overlay of geologic and geochemical themes used in weightsof-evidence analysis.

The probability that a deposit exists increases where the predictor themes areally overlap (green arrow). 


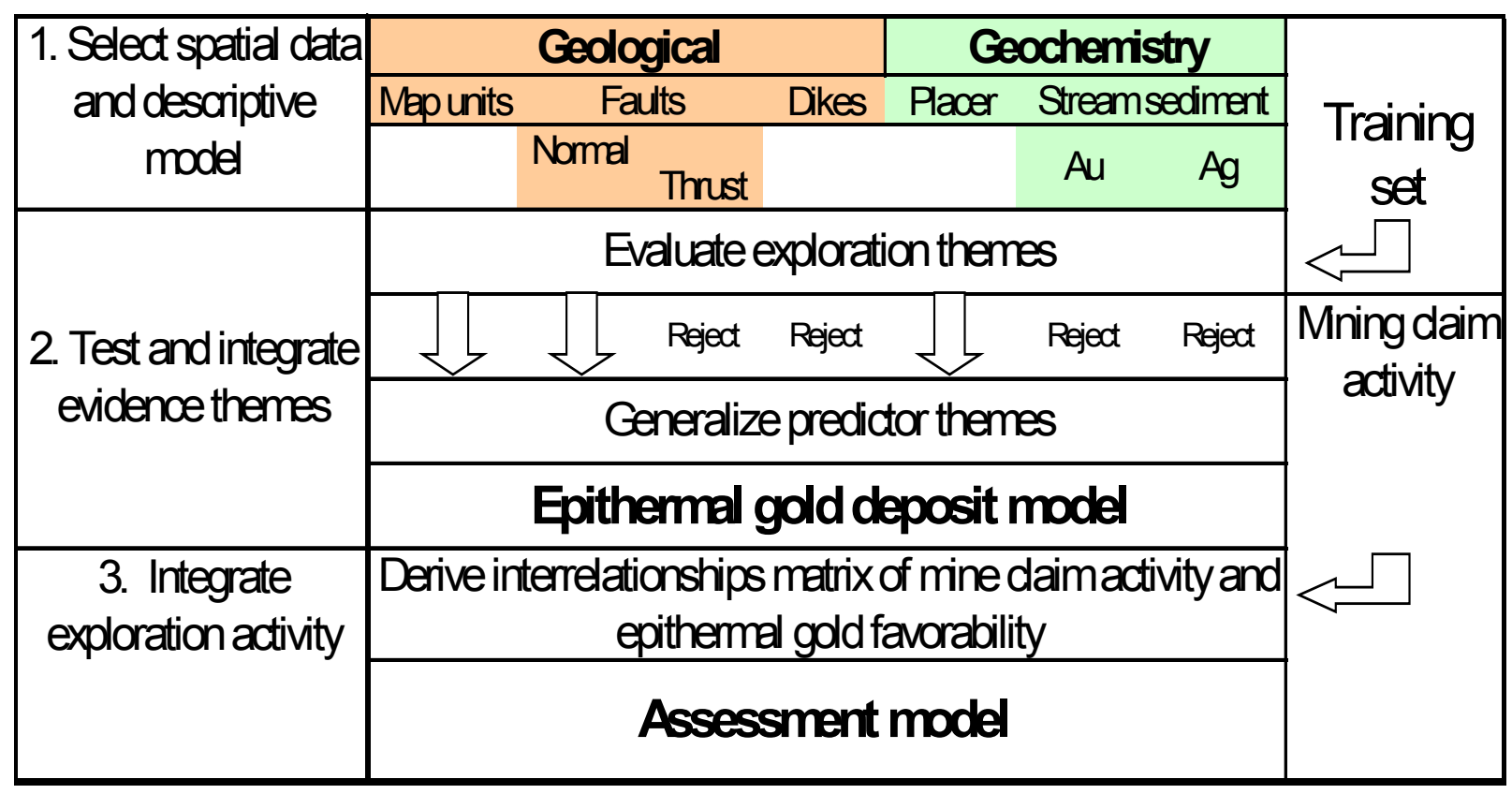

Figure 3. Flow diagram describing mineral assessment procedure for epithermal gold.

The first step in the analysis consists of assembling the evidence themes and training set for use in the analysis. The nature of this data depends on the descriptive model of the deposits sought. In step 2 of the analysis, each evidence theme is compared individually to the training set following the weights-ofevidence analysis procedures. Based on these results, themes are accepted or rejected based on calculated statistics (contrast, weights) that define probabilities. Acceptable themes of lithology, normal faults, and placer gold sites (predictors) are generalized based on an optimum buffer distance as indicated from the theme "peak" contrast values. The predictor themes are digitally added to form the model for undiscovered epithermal gold deposits. Using a probability approach, tracts are defined as nonpermissive, permissive, and favorable for containing undiscovered epithermal gold deposits. In step 3, mining claim data are assembled and used to indicate levels of mineral industry exploration activity. The next step in the analysis involves determining the relationship between the level of mineral industry exploration activity and the non-permissive, permissive and favorable tracts. These themes are digitally added to form the assessment model of mineral industry activity for undiscovered epithermal gold deposits. 
To prepare the mining claim activity theme, parcels containing mining claims were qualified as either containing historic (1980 or 1985), current (1990 or 1996), or consistent (current and historic). Historic, current, or consistent rankings occupy the x-axis on the resource model-activity model matrix. The y-axis is established by rank of favorable, permissive, or nonpermissive from the epithermal gold deposit model. Classes within this matrix were assigned levels of mineral industry exploration activity consisting of no activity, low activity, moderate activity, and highest activity. The assessment model was created according to guidelines set out in the matrix.

\section{Categorical or cumulative calculations?}

Weights calculations for weights of evidence are carried out using one or both of two different procedures, the categorical or cumulative weights calculations. The available data dictates the procedure followed. The categorical method is used where data occurs in unrelated and mutually exclusive categories (nominal or classificatory scale of measurement of Siegel, 1956, p. 22). The categories Yes and No and lithologic units on a geologic map are examples. See Weights Calculation in App. II.

Unlike the unrelated data categories, where data between categories are related (ordinal, interval, or ratio data after Siegel, 1956, p. 22), the calculation may be carried out on a cumulative weights fashion. Data occurring in ranks or on a temperature scale are examples.

The basic procedure for calculating cumulative weights is to digitally establish a series of buffers around line, point, or polygon features of the exploration theme being tested and, during the hypothesis-testing step, to calculate weights and contrast values for each buffer band. Buffer bands are arbitrary and vary in width from one to 1000 or more meters. Contrast is the difference between the calculated positive and negative weights on the map for the exploration theme "X". The buffer band with the maximum contrast value is the optimal buffer of that theme. The buffer band containing the optimal buffer defines the limit (starting at the line, point, or polygon and moving outboard) for an evidence theme. Data that occur within the optimum buffer of a theme are termed to lie inside the pattern while all other data lie outside the pattern. Inside and outside describe binary theme generalization that uses the optimum buffer distance to define this limit (or boundary). Themes are referred to as "generalized" to the limit defined by the optimum buffer band. See glossary (app. II). The final step in the procedure is to add all predictor themes to create the final model.

\section{Descriptive model for epithermal gold deposits}

The descriptive ore deposit model guides the selection of: (1) the training sites and (2) the procedure for testing the evidence themes by the weights-of-evidence analysis. Definitive study of gold-silver epithermal deposits at Republic (Full and Grantham, 1968), Golden Promise (Fifarek and others, 1996), and K-2 (Rasmussen and Gelber, written communication, 2000) formed a descriptive model for selecting the training set and to guide the analysis.

The area has the following characteristics that are generally consistent with the USGS descriptive model for hot spring-type Au-Ag (Berger, 1986):

- Major features. The district lies at the center of a region in north-central Washington exhibiting extensive, generally dacitic, volcanic activity of mid-Eocene age. Evidence of this activity consists of a wide range of flows, pyroclastic rocks and water-laid tuffaceous 
sediments. The northeast-trending Republic and Toroda Creek grabens, the major structural features preserve a large volume of these volcanic rocks. Movement along graben-bounding normal and low-angle, listric-normal faults appears to be coincident with cessation of volcanism, with uplift of the Kettle and Okanogan gneiss domes, and with gold mineralization. This suggests a genetic relationship between these events (Fox, 1994; Box, 1994). Gold deposits are formed in similar settings in southern California and southwest Arizona (Long, 1992).

- Alteration. Bleaching and alteration to clays is common; kaolinization of feldspars is related to widespread fracturing in the epithermal environment. Silicification is pronounced and adularia is present throughout the productive veins. Pyrite, chlorite, epidote and calcite are associated with hydrothermal alteration but the same minerals are not necessarily related to economic mineralization.

- Host rock. Veins favor hard or brittle rocks, such as intrusive porphyry or extrusive flow rocks. Veins, fault breccia, and hydrothermal breccia form along NW-trending, secondary, and sympathetic faults. Orientation of these and other faults can range from northeast to northwest. Banded, chalcedonic, and hydrothermal breccia veins that host the higher concentrations of gold and silver result from open-space filling in the boiling zone, and often are affected by post-mineral faulting. Low grade disseminated gold-silver values also occur in the porous, sericitized, pebbly zone of the basal lake bed sequence located stratigraphically above the veins.

\section{TRAINING SITES}

Training sites are a collection of mines, prospects or mineral occurrence sites having characteristics in common to those sought. Selection of the appropriate training sites within the limits of the study area is key to the analysis. Training sites were selected from the U.S.Geological Survey's Mineral Resource Database System (USGS, MRDS) (Boleneus, 1999a). Two other significant sites, Knob Hill Mine and K-2, were included from the US Bureau of Mines MAS/MILS database (USBM, 1995). These sites were sufficiently studied to infer confidently that they are related to epithermal gold mineralization. Informal rules for selecting a training sites dictate that chosen sites of epithermal gold mineralization are located both within the limits of the volcanic province of northeast Washington and within the study area. A set of training sites must be sufficiently large to obtain statistically significant results. Therefore simply selecting the significant deposits or only those exhibiting historic production did not provide enough geographically separated training sites. The number of sites selected is arbitrary. The fifty selected sites (App. I) that have common minimum characteristics could be related to either hot spring Au-Ag deposits (Berger, 1986), Creede epithermal deposits (Mosier and others, 1986), or Comstock epithermal vein deposits (Mosier, Singer, and Berger, 1986). See figure 1b. The area of each training site was assumed to be $1 \mathrm{~km}^{2}$ for the purpose of the analysis. This provides a prior probability $(p)$, the ratio of area of training sites to that of the area of study $(50 / 23600)$, of 0.0021 .

MRDS or MAS/MILS data indicated that 23 of the training sites are current or former producers, although this was not a requirement for selection. Five of these sites have produced significant quantities of ore (First Thought, Knob Hill, K-2, Kettle, Sheridan). Several sites (Ben Hur, Black Tail, Butte \& Boston, El Caliph, Insurgent, Last Chance, Little Cove, Lone Pine, Morning Glory, Mountain Lion, Pearl, Princess Maude, Quilp, San Poil, Surprise, Republic, Tom 
Thumb, and Trade Dollar) were small, but important producing sites that lay along the important 6.5-km-long Eureka fault trend (Full and Grantham, 1968) that extends northwest from the city of Republic. A large number of sites concentrated in a small area along the Eureka fault trend near Republic raised concern that a bias may be inadvertently introduced. Also mines adjacent to the Eureka fault are vein-type mines, but it is not known whether the training set is biased toward vein-type mines because information to make a judgment is not available from all sites.

Randomized methods of site selection were not investigated. Golden Promise was not included in the set because an accurate location was unavailable at time of the analysis. Concern about its omission was dismissed because it lies within 300-500 $\mathrm{m}$ (or within the $1 \mathrm{~km}^{2}$ site area) of three included sites, Black Tail, Surprise, and Last Chance.

\section{ANALYSIS OF GEOLOGIC PATTERNS FOR EPITHERMAL MODEL}

The objective of weights-of-evidence analysis is the analysis of areal proximity of the training set in comparison to other features (geological map features, geophysical features, alteration features, geochemical features and so) defined by points, lines or polygon areas. The results of three proximity analyses are described in this section. This analysis is not meant as an exhaustive treatment in this setting, or that it uses all available data, but merely demonstrates its strict application in a relatively well-studied location.

Based on the descriptive model for epithermal gold deposits in northeast Washington, several themes were assembled from various sources and tested as possible predictor themes (table 1). Themes tested and accepted as predictor themes, lithologic (volcanic) units, normal faults, gold placer sites, are in italic typeface; other themes were investigated but failed to meet the proximity criteria of the analyses. The acceptable theme data, called predictor themes, describe the lithologic, structural, and geochemical characteristics of the resource model as described below. A brief explanation is given in the next section of reason for failure of the igneous dikes (Eocene) theme to qualify as a predictor theme. The reason that the thrust faults and gold and silver silt geochemistry themes failed to qualify as predictor themes is beyond the report scope.

\section{Proximity to lithologic units}

\section{$\underline{\text { Data preparation }}$}

Geologic map information in digital format was used to perform this analysis. Geologic theme data relied on 1:100,000-scale mapping completed by Washington Department of Natural Resources for Omak (Gulick and Korosec, 1990), Chewelah (Waggoner, 1992), Colville (Joseph, 1990a), Oroville (Stoffel, 1990a), Nespelem (Joseph, 1990b), and Republic (Stoffel, 1990b) quadrangles. Arc/Info coverages of these geologic quadrangles were converted into digital form at Wash. DNR (Schuster and Harris unpublished data) and provide to USGS in preliminary form. USGS divided these sub-coverages consisting of lithology, faults, folds, and dikes. The Wash. DNR coverages will eventually be published but may differ from those we used. Sub-coverages have spatial orientation links to a detailed data table containing topological and geologic data. Each of the four Arc/Info sub-coverages for the six quadrangles was combined into a seamless coverage corresponding to the limits of the study area. In the process, 670 lithologic units on the six quadrangle maps were generalized to 169 lithologic units in constructing the geologic map. All sub-coverages were converted to ArcView shape files and grid files (Boleneus and Causey, 
2000). Because the many Quaternary units differed considerably between the 1:100,000-scale maps, they could not be correlated from map to map and were abandoned in construction of the geologic map. Instead, one Quaternary undivided (Q) unit was used to describe all Quaternary units.

Table 1. Themes investigated for epithermal gold deposit model.

[Themes in italic typeface were accepted as predictor themes. Other themes were tested but rejected as predictor themes.]

\begin{tabular}{lll}
\hline Theme & Purpose & Source of data \\
\hline $\begin{array}{l}\text { Predictors: } \\
\begin{array}{l}\text { Lithologic units (i.e. } \\
\text { Eocene volcanic rocks) }\end{array}\end{array}$ & Specify extent of host rocks & $\begin{array}{l}\text { Lithology coverage (Wash. } \\
\text { DNR digital geology) }\end{array}$ \\
\hline $\begin{array}{l}\text { Normal (steep) faults } \\
\text { Placer gold sites }\end{array}$ & Indicate favored hosts for veins & $\begin{array}{l}\text { Faults coverage (Wash. DNR } \\
\text { digital geology) }\end{array}$ \\
\hline Not predictors: & Identify eroded gold deposits & $\begin{array}{l}\text { MRDS (USGS), MAS/MILS } \\
\text { (USBM) }\end{array}$ \\
\hline $\begin{array}{l}\text { Dikes (Eocene) } \\
\begin{array}{l}\text { Low-angle, listric } \\
\text { ("thrust") faults }\end{array}\end{array}$ & $\begin{array}{l}\text { Denote deep crustal structures } \\
\text { possibly related to detachment faults }\end{array}$ & $\begin{array}{l}\text { Faults coverage (Wash. DNR } \\
\text { digital geology) }\end{array}$ \\
\hline $\begin{array}{l}\text { Gold and silver assays } \\
\text { from stream sediment } \\
\text { samples }\end{array}$ & Identify eroded gold deposits & $\begin{array}{l}\text { Geochemistry data on } \\
\text { Okanogan and Colville Forests } \\
\text { (Boleneus and Chase, 1999a) }\end{array}$ \\
\hline
\end{tabular}

\section{Procedure}

The weights-of-evidence analysis conducted upon lithologic units can be generally described as occurring in three steps. First, a categorical (weights) analysis was used to select a specific group of lithologic units from the 169 lithologic units that are areally-associated with the training set. Second, a cumulative (weights) analysis was performed on the specific group of lithologic units to improve the predictor theme, and third, a cumulative analysis was performed on data consisting of acid-to-intermediate Eocene-age dikes. A cumulative analysis is appropriate in the latter two steps because buffer bands are constructed around the features.

\section{$\underline{\text { Categorical analysis }}$}

The categorical analysis was used to select specific lithologic units nearest to the deposits. This procedure determines the areal association between the training set and the geologic units that occur at the surface. It is recognized that geologic units in the subsurface may often differ from surface units. Because of the areal association (i.e. proximity) with the training set, the following nine lithologic units were selected: Eck, Evkct, Evst, Evsf, Evkf, Eco, Eid, TRPMmsv, and Q (table 2a). A description of these units is given below. These lithologic units were selected based on calculated weights and contrast values. Where the contrast value is positive, the units are considered inside the pattern of prediction ("inside pattern"), if the contrast is 0.0 or less, the unit is outside the pattern ("outside pattern"). Where the contrast values range 
from 0.01 to 1.0 the association is considered mild to moderate, where the contrast ranges from 1 to 2 the level of prediction is strong; where the contrast value is 2.0 or greater the association is considered extremely predictive. The areal extents of the lithologic units having positive contrast values clearly define the limits of the Republic and Toroda Creek grabens (fig. 4a). The remaining 160 units not selected are shown in Appendix I (table 2b). The Quaternary undivided (Q) unit is not shown in this figure.

The Eocene rock strata selected above consist of three successive units. The lowermost unit, the O'Brien Creek Formation (Eco), consists of varied pyroclastic and mudflow units formed by explosive quartz latite volcanism. The Sanpoil Volcanics consist of rhyodacitic lavas and breccias (Evsf, flows; Evst, tuffs and volcanic breccia). The uppermost unit, Klondike Mountain Formation consists of flows, breccias, and domes in addition to bedded tuffs and lake bed deposits (Eck, volcaniclastic rocks and sediments; Evkct, volcanic conglomerate and tuffs; Evkf, flows) according to Pearson and Obradovich (1977).

Six Eocene volcanic or sedimentary rock units are considered non-prospective for epithermal deposits and were not selected during the analysis. These include Evsv (volcaniclastic unit of the Sanpoil Volcanics in Nespelem and Chewelah quadrangles), Evf (unnamed flows), Evcg (unnamed volcanic conglomerate), Evcl (unnamed volcaniclastic rocks), Ev (unnamed volcanics undivided) and Ec (Tiger Formation near Newport, Washington).

Table 2(a). Proximity analysis for lithologic map units.

[Results are categorical and are ranked by contrast. The high inside-the-pattern areas (bold typeface) are separated from low inside-the-pattern area (italic typeface) at a contrast value of 2. Contrast values $>2$ are considered extremely predictive. See Kemp and others, 1999 and App. II, Glossary. See Appendix I for Table 2b. Quaternary (Q) unit is shown because it contains 15 training sites; $\mathrm{W}^{+}$and $\mathrm{W}^{-}$are weights; Eck, Evkc, Evkf - Klondike Mountain; Evst, Evsf - Sanpoil Volcanics; Eco -O’Brien Creek Formation; Eid Dikes (Eocene); TRPMmsv - metavolcanic rocks, undivided; Q - Quaternary]

\begin{tabular}{crrrrrrr}
\hline $\begin{array}{l}\text { Lithologi } \\
\text { c symbol }\end{array}$ & $\begin{array}{c}\text { Area, } \\
\mathrm{km}^{2}\end{array}$ & $\begin{array}{c}\text { Number } \\
\text { of } \\
\text { training } \\
\text { sites }\end{array}$ & $\mathrm{W}^{+}$ & $\mathrm{W}^{-}$ & Contrast & Rank \\
\hline Eck & $\mathbf{4 4}$ & $\mathbf{2 6 . 3}$ & $\mathbf{4}$ & $\mathbf{4 . 4 6 8 6}$ & $\mathbf{- 0 . 0 8 2 5}$ & $\mathbf{4 . 5 5 1 0}$ & Inside pattern, high \\
Evkct & $\mathbf{6 5}$ & $\mathbf{2 9 . 0}$ & $\mathbf{2}$ & $\mathbf{3 . 5 8 4 4}$ & $\mathbf{- 0 . 0 3 9 7}$ & $\mathbf{3 . 6 2 4 1}$ & Inside pattern, high \\
Evst & $\mathbf{7 5}$ & $\mathbf{1 7 . 2}$ & $\mathbf{1}$ & $\mathbf{3 . 4 0 0 7}$ & $\mathbf{- 0 . 0 1 9 5}$ & $\mathbf{3 . 4 2 0 2}$ & Inside pattern, high \\
Evsf & $\mathbf{2 1}$ & $\mathbf{6 5 6 . 2}$ & $\mathbf{2 0}$ & $\mathbf{2 . 7 2 7 3}$ & $\mathbf{- 0 . 4 8 4 3}$ & $\mathbf{3 . 2 1 1 6}$ & Inside pattern, high \\
Evkf & $\mathbf{6 1}$ & $\mathbf{2 1 2 . 9}$ & $\mathbf{5}$ & $\mathbf{2 . 4 5 9 6}$ & $\mathbf{- 0 . 0 9 6 8}$ & $\mathbf{2 . 5 5 6 3}$ & Inside pattern, high \\
Eco & 20 & 70.6 & 1 & 1.9446 & -0.0173 & 1.9619 & Inside pattern, low \\
Eid & 16 & 163.4 & 1 & 1.0968 & -0.0135 & 1.1103 & Inside pattern, low \\
TRPMmsv & 9 & 176.5 & 1 & 1.0193 & -0.0130 & 1.0323 & Inside pattern, low \\
$\mathrm{Q}$ & 5 & $\underline{9712.0}$ & $\underline{15}$ & -0.2844 & 0.1520 & -0.4364 & Outside pattern \\
\hline
\end{tabular}




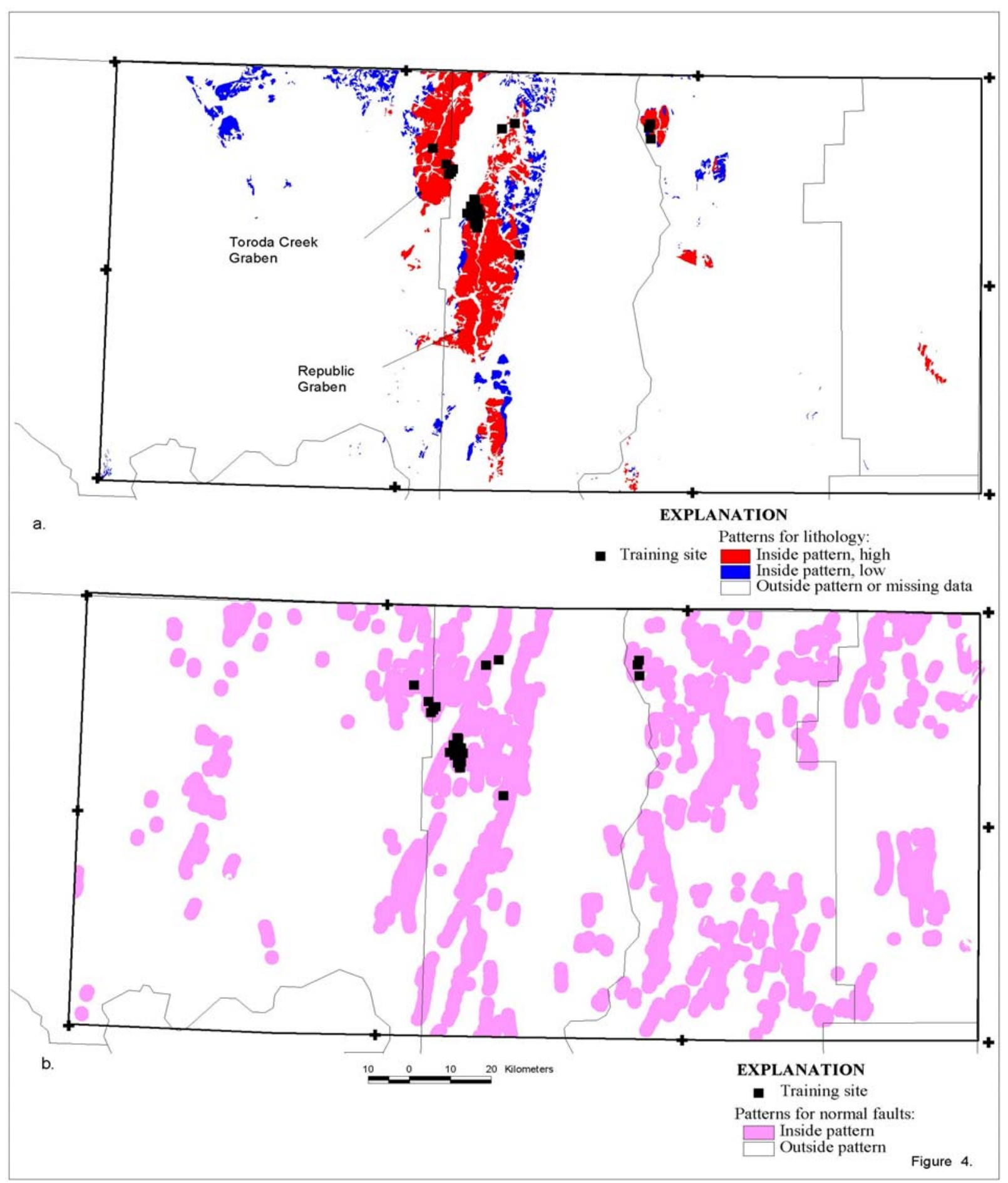

Figure 4. Lithologic units pattern and normal faults pattern maps.

(a) Shows extent of pattern for lithology units selected by the categorical analysis. The "inside-thepattern" areas clearly define the limits of the Toroda Creek and Republic grabens. (b) Predictor pattern of $1700 \mathrm{~m}$ radius surrounding all normal faults (buffer and faults are not shown). Training sites are shown. 


\section{Discussion of categorical data}

The nine units consisting of Eck, Evkct, Evst, Evsf, Evkf, Eco, Eid, TRPMmsv were selected within the predictor theme because the contrast values $>0$. The group consisting of lithologic units of the Klondike Mountain Formation and Sanpoil Volcanics (bold typeface in table 2) received a contrast value $>2.0$ and are assigned the inside the pattern, high ranking. This could be expected because gold deposits occur within the Sanpoil Volcanics. Three other units, consisting of O'Brien Creek Formation, Eocene dikes and meta-volcanics, undivided, received an inside the pattern, but lower rank (italic typeface) and their association with gold deposits is less clear. The Quaternary undivided (Q) unit lies outside the pattern and is considered an area of missing data because the composition of the underlying bedrock remains unknown. Since all lithologic units in the table (except Q) have high contrast values, they have strong to extremely predictive areal associations with the training set. From this association, it can be concluded that area covered by the eight lithologic units (selected units) have a greater likelihood for containing undiscovered epithermal gold deposits.

The numbers of training sites found inside the borders of each lithologic unit are shown in table 2a. The Evsf unit, consisting of flows of the Sanpoil Volcanics, contains the largest number of training sites. These results were anticipated since the best deposits in the Republic, Curlew and Orient areas occur near the top of the Sanpoil Volcanics just below the contact with the overlying Klondike Mountain Formation (Fifarek, Devlin, and Tschauder, 1996; Steven Box, written commun, 2001). The Evsf also occupies an area of flow units of the most common host (Muessig, 1967; Full and Grantham, 1968). As a group, the five units that rank inside the pattern, high are extremely predictive and contain 32 of the 50 training sites. Three other training sites occur inside the pattern, low in the O'Brien Creek Formation, Eocene dikes, and undivided metavolcanic rocks. These three units are all considered strongly predictive patterns. The 15 sites found with the Quaternary $(\mathrm{Q})$ unit are troublesome and represent the principal reason to perform the cumulative analysis. The $\mathrm{Q}$ unit is problematic because it contains such a large number of the training sites with unknown bedrock composition below.

The categorical analysis of lithologic units provides a good predictor theme. The eight classes have been summarized to three classes, high-inside pattern and low-inside pattern, and outside pattern. Before carrying out the cumulative analysis for lithologic units, the results of the categorical analysis of lithologic units were run in the final model to observe that outcome. It is an advantage of weights-of-evidence that several scenarios can be tested in a short time. In the final model, one predictor theme of categorical data containing three classes was found to unnecessarily bias the results in favor of lithology ${ }^{4}$. The problem that the Quaternary unit contains 15 training sites was mentioned. Both of these problems were overcome by deriving a cumulative analysis of the selected lithological units for the final model. In the following discussion the categorical results (above) are re-analyzed using a cumulative analysis. The cumulative analysis results replaced the categorical results as an improved predictor theme of

\footnotetext{
${ }^{4}$ An important assumption of weights-of-evidence analysis is that predictor themes must be independent (see conditional independence in Glossary) of one another. Results from both the categorical and cumulative analysis were separately integrated into final epithermal gold models and it was found that the cumulative analysis results provided the highest independence.
} 
lithologic units. The cumulative analysis results are a better predictor theme because of higher contrast values and they account for 47 of the 50 training sites.

\section{Cumulative analysis}

The hypothesis, that one pattern containing the eight selected lithologic units is spatially correlated with the training set, was tested. In this step, the cumulative analysis was performed on the group of eight lithologic units (Eck, Evkct, Evst, Evsf, Evkf, Eco, Eid, TRPMmsv) from the categorical analysis. The eight units were grouped and analyzed as a single area. First, a series of buffer bands each of 50-m width were digitally constructed around the area before performing the analysis. The cumulative results (table 3 ) show the contrast values forms a peak at the $150 \mathrm{~m}$ buffer radius. This area encompasses 47 of the 50 training sites. The distance where the contrast is highest, forms a distinct peak, and accounts for the larger number of the training sites is the optimum distance. The optimum distance defines the limit of the predictor pattern (inside the pattern). All remaining areas, including the three missed training sites, are outside the pattern. Inside the pattern includes the area of all eight grouped units and extends outboard 150 $\mathrm{m}$ from their border. The peak contrast of 5.32 is an improvement over the best contrast of 4.55 in the categorical discussion. Its only class is inside the pattern (replaces three classes of categorical results). The conclusion is that the buffered pattern of lithologic units is an extremely good predictive theme based on the level of the contrast value. This theme will be used later in the data integration step as one of three themes to create the epithermal gold deposit model. A separate figure was not prepared of the results of the cumulative analysis since no differences can be observed at the scale of the map (fig. 4a).

Table 3. Proximity analysis for eight selected lithologic units.

[The optimum buffer distance at $150 \mathrm{~m}$ highlighted in bold typeface is the limit of "inside the pattern"(inside pattern). Buffer distance, area, and number of training sites are cumulative. At the limit of the $150-\mathrm{m}$ radius pattern, it is noted that 47 of the 50 training sites occur within the optimal pattern. That area beyond $150 \mathrm{~m}$ is considered outside the pattern and contains three training sites.]

\begin{tabular}{cccccc}
\hline Buffer distance, $\mathrm{m}$ & Area, sq. km. Number of training sites & $\mathrm{W}^{+}$ & $\mathrm{W}^{-}$ & Contrast \\
\hline 50 & 1493.8 & 40 & 2.59 & -1.55 & 4.14 \\
100 & 1630.8 & 45 & 2.62 & -2.24 & 4.86 \\
$\mathbf{1 5 0}$ & $\mathbf{1 7 7 6 . 8}$ & $\mathbf{4 7}$ & $\mathbf{2 . 5 8}$ & $\mathbf{- 2 . 7 4}$ & $\mathbf{5 . 3 2}$ \\
200 & 1890.6 & 50 & -- & -- & -- \\
\hline
\end{tabular}

\section{Dikes theme}

Small-scale, shallow intrusive features of intermediate to acid composition, or dikes, were expected to show the area of extensive dacitic volcanic activity of the epithermal event. Dikes having a basic or alkalic composition or those of other than Eocene age were excluded. Accordingly, such a group of dikes of Eocene age was assembled from the dikes coverage (Schuster and Harris, unpublished data) and tested as a possible predictor theme. Results from analysis showed the optimum contrast occurred at $9000 \mathrm{~m}$. The conclusion was drawn that such a pattern had a weak yet positive spatial relationship to the training set. The pattern outlined the huge epithermal volcanic field centered in northern Ferry County. However, the results (not 
shown) were not used as a predictive theme because they lacked geological significance, covered an extensive area, and some of the dikes were already included in the Eid lithologic unit of the previous categorical and cumulative analysis. Such a buffer seemed too wide, not a particularly useful unbiased predictor layer, and unlikely to provide a significant improvement of the final epithermal model. Another problem with dikes theme is that the small dikes are not universally included on 1:100,000-scale geologic maps and so all dikes may not be available for the analysis.

\section{Proximity to normal faults}

Epithermal deposits develop along faults and fractures that formed in response to the region's major structural adjustments during volcanic events (Full and Grantham, 1968). Increased permeability along faults probably controlled the pathways followed by fluids that deposited metals and gangue minerals. Therefore faults are considered as potential localizers for ore deposition. A hypothesis that all normal faults controlled mineralization was tested. The faults sub-coverage contained 5148 fault segments of all types and 4480 normal fault segments were selected for the analysis. These results (not shown) were rejected because the contrast value was not definitive. The conclusion was drawn that such a large group of normal faults was not spatially related to the training set.

A second hypothesis addressing control on mineralization by normal faults of a particular orientation was formulated and tested using a modified version of the normal fault coverage. In this version, faults were classified by compass orientation and type. The northerly-trending structural trends of normal faults are significant sites for deposition of gold. It is clear from the geologic map of northeast Washington (Stoffel and others, 1991) that major structural trends in Eocene rocks occur in or near the Republic graben along azimuths ranging from $10^{\circ}$ to $20^{\circ}$. Vein azimuths in the Eureka fault trend near Republic range from $330^{\circ}$ to $10^{\circ}$ (Muessig, 1967). In a comparison of all faults occurring in all compass directions in the study area, the larger proportion of normal fault segments occur in the range from $345^{\circ}$ to $30^{\circ}$. The trend of this test group is consistent with the dominant fault and vein direction of northeast to northwest (Full and Grantham, 1968). The selection excluded faults classified as thrust faults, low-angle normal faults, or those of unknown type. Of a total of 4480 normal fault segments, a group of 1807 normal faults occur within the $345^{\circ}$ to $30^{\circ}$ interval (table 4) and subjected to the hypothesis testing.

Table 4. Number of normal fault segments whose orientations range from $345^{\circ}$ to $30^{\circ}$.

\begin{tabular}{|c|c|}
\hline $\begin{array}{c}\text { Fault azimuth } \\
\text { group }\end{array}$ & Number of fault segments \\
\hline $345-350^{\circ}$ & 153 \\
\hline $351-360^{\circ}$ & 358 \\
\hline $1-10^{\circ}$ & 426 \\
\hline $11-20^{\circ}$ & 459 \\
\hline $21-30^{\circ}$ & 411 \\
\hline Total & $18 \overline{807}$ \\
\hline
\end{tabular}



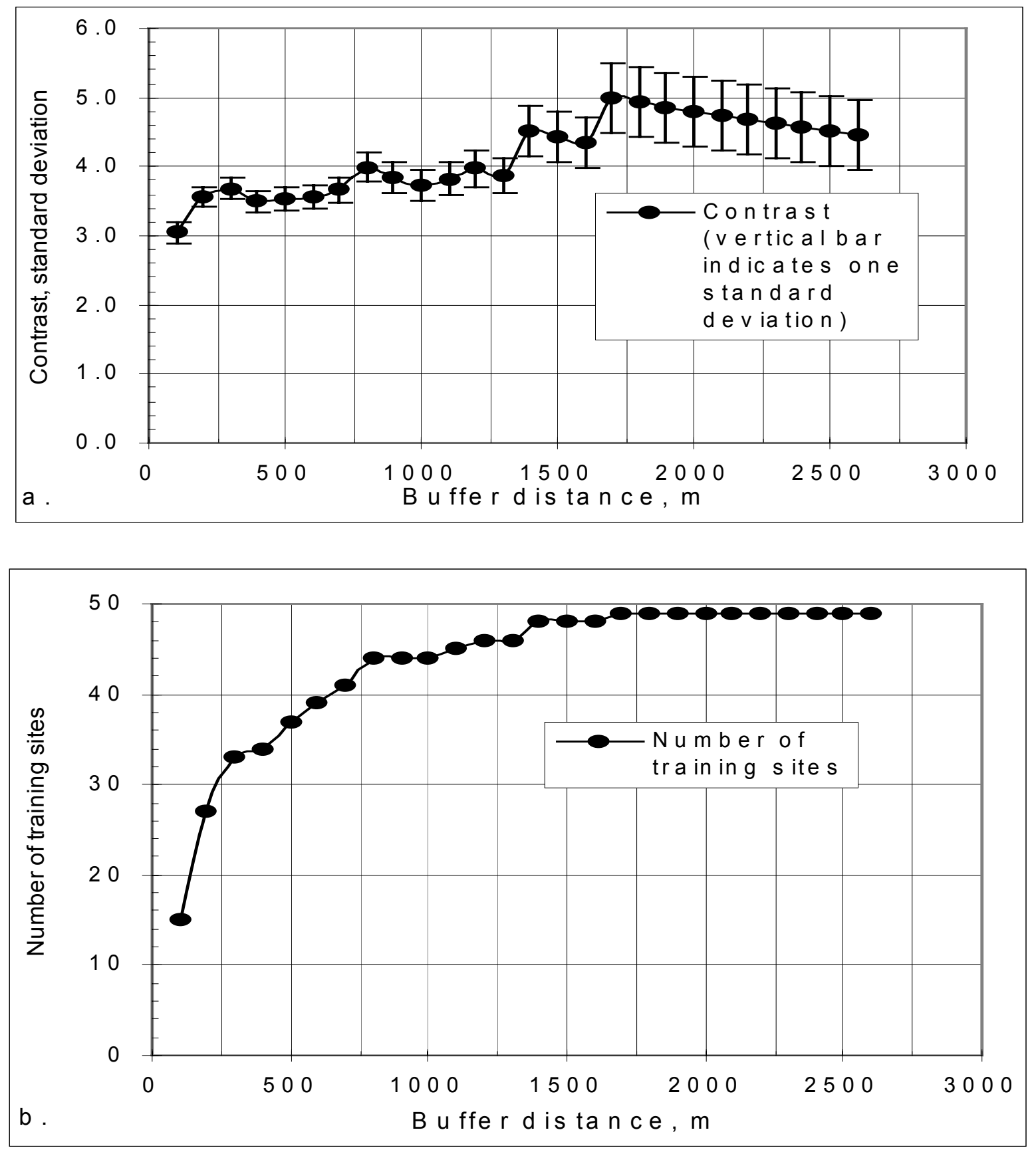

Figure 5. Normal faults pattern analysis.

(a) Contrast versus buffer distance for normal faults theme. Shows peak contrast occurring at $1700 \mathrm{~m}$ distance from each fault. Error bar represents one standard deviation. (b) Number of training sites versus buffer distance at successive distance from faults. Shows that 49 training sites are captured within the 1700-m buffer distance. 
The $345^{\circ}$-to- $30^{\circ}$-oriented normal fault group was buffered with $100 \mathrm{~m}$ wide bands extending in all directions from each fault to $2700 \mathrm{~m}$. The cumulative proximity analysis results indicate that the contrast peaks at $1700 \mathrm{~m}$ (fig. 5a) at a contrast value of 4.99 (table 5). The faults pattern (inside pattern) area includes this particular group of normal faults and the area extending outboard to the 1700-m buffer. The pattern includes 49 of the 50 training sites (fig. $5 \mathrm{~b}$ ). The pattern is presented in generalized form (fig. 4b), as the normal fault segments are too numerous to show at the scale of the map. We conclude that the normal faults pattern is an extremely good predictive theme based on the contrast value. The pattern is used later as a predictor theme in the epithermal gold model.

Table 5. Proximity analysis for normal faults.

[The optimal buffer distance at $1700 \mathrm{~m}$ (bold typeface) represents the limit of "inside the pattern" for normal faults. It encloses 49 of 50 training sites. Buffer distance, area, and number of training sites are cumulative. The area outboard of $1700 \mathrm{~m}$ is "outside the pattern".]

\begin{tabular}{cccccc}
\hline $\begin{array}{c}\text { Buffer distance, } \\
\mathrm{m}\end{array}$ & Area, $\mathrm{km}^{2}$ & $\begin{array}{c}\text { Number of } \\
\text { training sites }\end{array}$ & $\mathrm{W}^{+}$ & $\mathrm{W}^{-}$ & Contrast \\
\hline 100 & 498.0 & 15 & 2.72 & -0.34 & 3.05 \\
200 & 813.9 & 27 & 2.81 & -0.74 & 3.56 \\
300 & 1161.9 & 33 & 2.65 & -1.03 & 3.69 \\
400 & 1500.5 & 34 & 2.42 & -1.08 & 3.50 \\
500 & 1897.5 & 37 & 2.27 & -1.27 & 3.54 \\
600 & 2243.5 & 39 & 2.15 & -1.42 & 3.57 \\
700 & 2582.6 & 41 & 2.06 & -1.60 & 3.66 \\
800 & 2949.6 & 44 & 2.00 & -1.99 & 3.99 \\
900 & 3337.2 & 44 & 1.87 & -1.97 & 3.85 \\
1000 & 3709.0 & 44 & 1.76 & -1.96 & 3.72 \\
1100 & 4043.8 & 45 & 1.70 & -2.12 & 3.82 \\
1200 & 4372.9 & 46 & 1.64 & -2.33 & 3.97 \\
1300 & 4771.0 & 46 & 1.56 & -2.31 & 3.86 \\
1400 & 5114.4 & 48 & 1.53 & -2.99 & 4.51 \\
1500 & 5468.0 & 48 & 1.46 & -2.97 & 4.43 \\
1600 & 5781.2 & 48 & 1.40 & -2.95 & 4.35 \\
$\mathbf{1 7 0 0}$ & $\mathbf{6 1 2 1 . 9}$ & $\mathbf{4 9}$ & $\mathbf{1 . 3 7}$ & $\mathbf{- 3 . 6 2}$ & $\mathbf{4 . 9 9}$ \\
1800 & 6440.3 & 49 & 1.32 & -3.61 & 4.92 \\
1900 & 6772.2 & 49 & 1.27 & -3.59 & 4.85 \\
2000 & 7092.3 & 49 & 1.22 & -3.57 & 4.79 \\
2100 & 7375.1 & 49 & 1.18 & -3.55 & 4.73 \\
2200 & 7694.6 & 49 & 1.14 & -3.53 & 4.67 \\
2300 & 7977.1 & 49 & 1.10 & -3.52 & 4.62 \\
2400 & 8253.0 & 49 & 1.07 & -3.50 & 4.57 \\
2500 & 8560.4 & 49 & 1.03 & -3.48 & 4.51 \\
2600 & 8840.1 & 49 & 1.00 & -3.46 & 4.46 \\
2700 & 9111.9 & 50 & & & \\
\hline
\end{tabular}

\section{Proximity to placer gold sites}

Several geochemical themes were evaluated as predictors of epithermal deposits. Among these, gold and silver analyses from stream sediment samples (Boleneus and Chase, 1999) were tested but were rejected as predictor themes. These were rejected because no optimum contrast 
level could be determined and because very large buffer distances failed to capture a substantial number of training sites. We speculated that the difficulty in using the gold-silver geochemistry theme is related to incomplete coverage of the silt geochemistry sampling sites. The gold and silver silt sample sites were restricted to public lands in national forests while the majority of the training sites are found on private lands. These results are not shown. Gold and silver analytical values from NURE spring and stream water samples may be a reasonable geochemistry theme but it was not tested. The disadvantage in having two geochemistry themes is similar to the problem with two lithologic themes discussed above.

We anticipated that placer gold mines would be a positive indicator of proximity to gold mineralization because they could indicate eroding deposits somewhere upstream. Gold placers are a likely indicator because winter precipitation is heavy and spring stream flow is strong. A total of 67 placer sites were obtained from the U.S. Geological Survey MRDS and US Bureau of Mines MILS databases (Boleneus, 1999a). These include all placer sites available from within the study area. The only criteria applied were that either gold was reported in placer form or was mined from placer deposits (Appendix I).

Using the proximity analysis, the hypothesis was tested that placer gold sites spatially correlate with the training sites. The 1000-m-wide buffer bands (colored) were first drawn around each placer gold site (fig. 6a) and extend outward to a radius of 10,000 m. The bands were made in the same way for the lithologic units (not shown) and normal faults themes (not shown). Proximity analysis results indicate that the contrast peaks at $4000 \mathrm{~m}$ (fig. 7a) at a contrast value of 3.70 (table 6). The area inboard of the peak contrast at $4000 \mathrm{~m}$ encloses 43 of the 50 training sites (fig. 7b). Based on this analysis, the $4000 \mathrm{~m}$ buffer is chose as the optimum distance of the predictor pattern. We conclude that the pattern (fig. 6b) for placer sites is an extremely good predictor pattern based on this contrast value. The generalized placer predictor theme is the third of three predictor themes in the epithermal gold model.

\section{$\underline{\text { Discussion }}$}

There was some concern that the circular buffer pattern for placers may be misleading because they are not pointed upstream toward the source of the gold. However, the density of points was insufficient to distinguish any direction. A possible disadvantage is that an age or geologic unit association cannot be established between the placer gold and training sites. We found these concerns were negated in the final model by the interaction of the placer sites with the other predictor layers.

The seven of the 50 training sites occurring outside the placer sites pattern are a concern. The explanation may be related to discovery of hidden deposits, K-2 and Kettle. K-2 and Kettle mines are two examples of the seven excluded training sites. Echo Bay Inc. (M. Rasmussen and C. Gelber, verbal communication, 2000), operator of both mines, indicated that both deposits were eventually discovered after completing follow-up sampling of anomalous gold values found by extensive proprietary stream silt sampling in the nearby, east-west drainage. Deposits are hosted in Eocene Sanpoil Volcanics and found drilling beneath thick Quaternary overburden. The lack of placer gold near these hidden deposits may also be due to the concealing Quaternary overburden. This explanation eases the concern that 7 of the 50 occurred outside the pattern. 


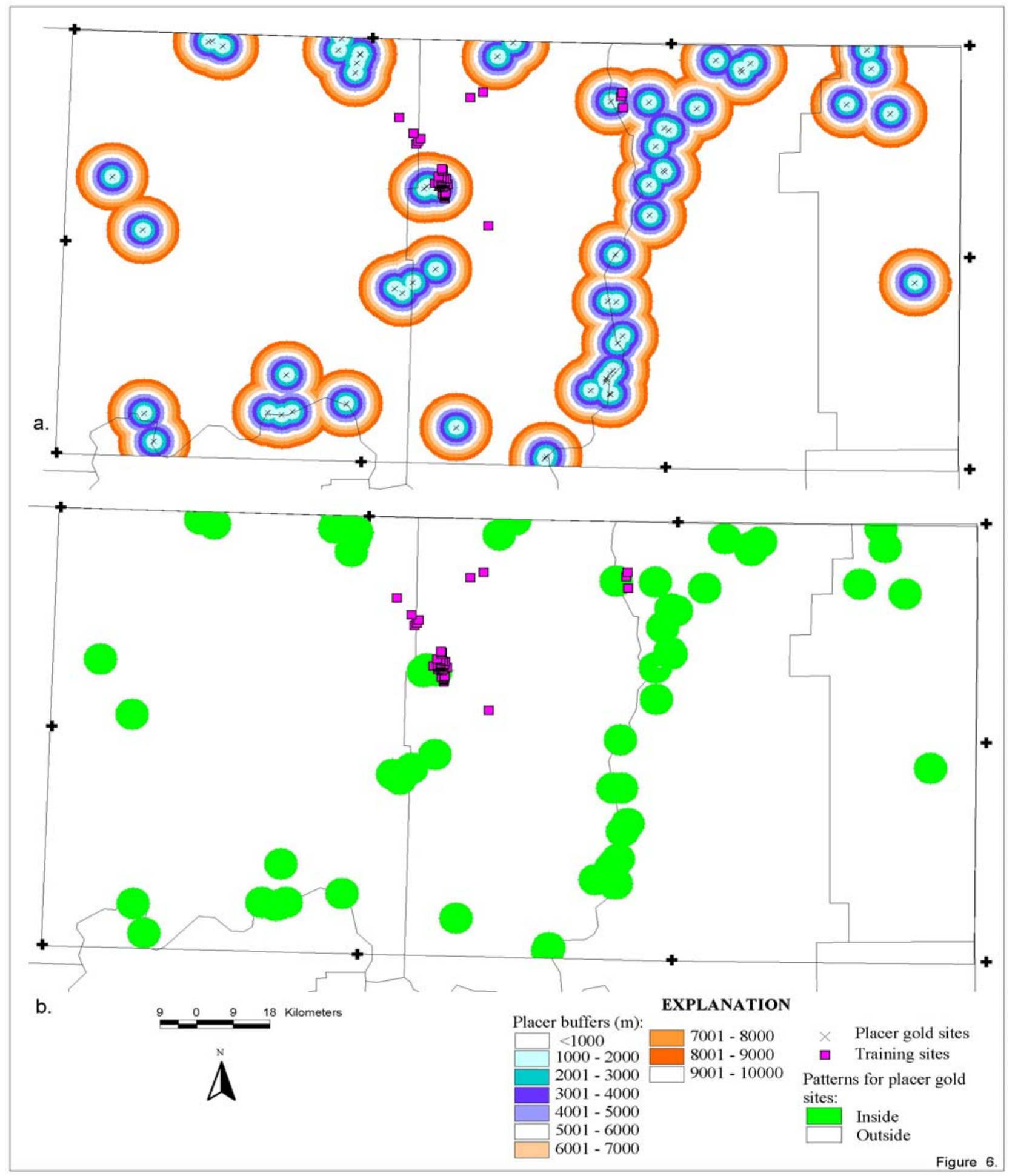

Figure 6. Placer gold pattern map

(a) Ten, 1000-m wide buffer bands (multi-colored) created around placer sites before analysis. (b) Shows optimum $4000 \mathrm{~m}$ radius pattern as a result of the analysis. Placer sites occur at center of each circular pattern (not shown). Training sites are also shown. 

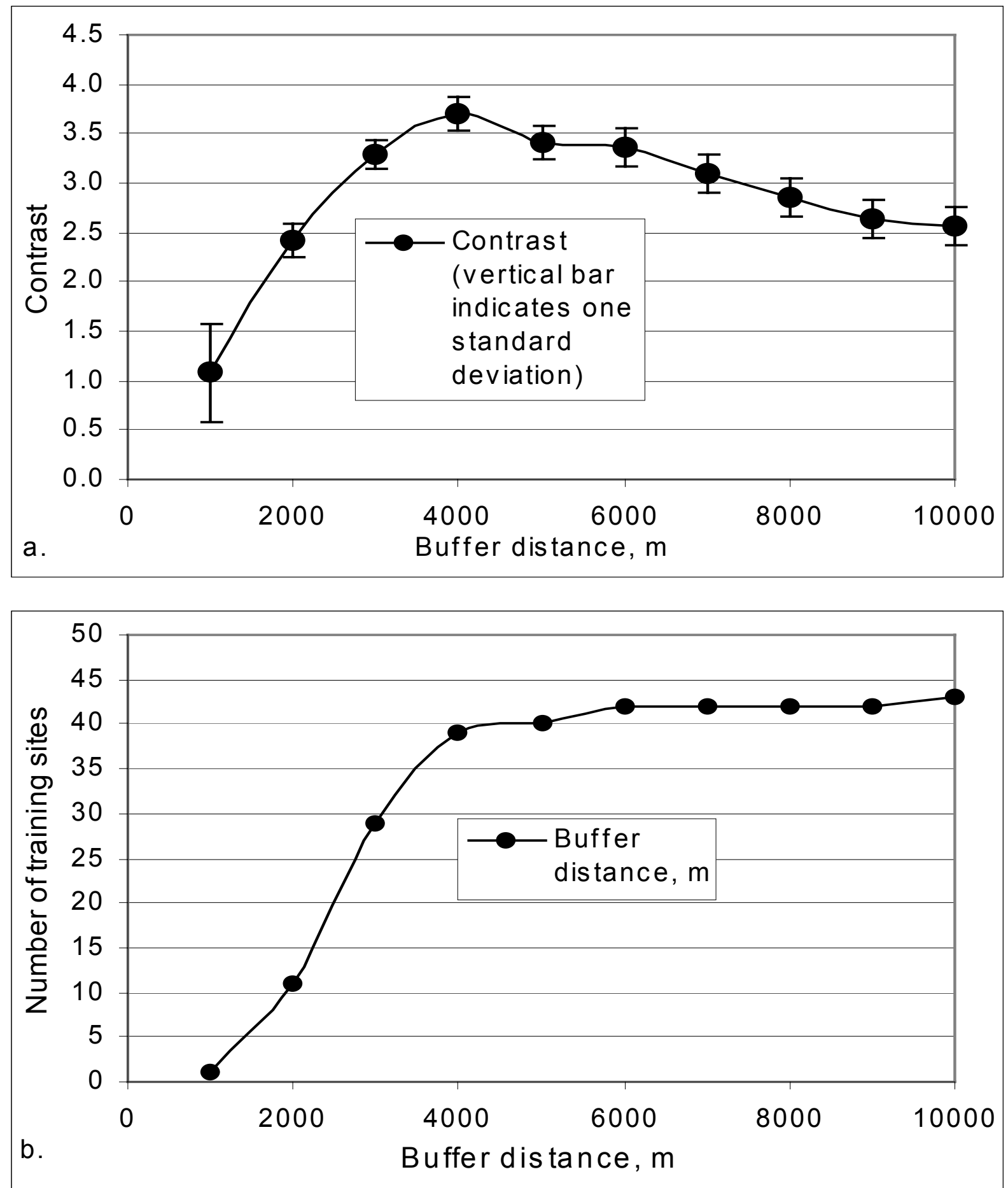

Figure 7. Placer gold pattern analysis.

(a) Shows contrast (and standard deviation as a measure of error) versus buffer distance. Buffers are $1000 \mathrm{~m}$-wide colored bands constructed around each placer gold site shown in previous figure. (b) Shows cumulative number of training sites captured within successive buffer bands versus distance. The 4000-m distance corresponds to the optimum distance established above. 
Table 6. Proximity analysis for placer gold sites.

[The optimal buffer distance at $4000 \mathrm{~m}$ (bold typeface) establishes the limit of "inside the pattern". Buffer distance, area, and number of training sites are cumulative.]

\begin{tabular}{cccccc}
\hline $\begin{array}{c}\text { Buffer distance, } \\
\mathrm{m}\end{array}$ & Area, $\mathrm{km}^{2}$ & $\begin{array}{c}\text { Number of training } \\
\text { sites }\end{array}$ & $\mathrm{W}^{+}$ & $\mathrm{W}^{-}$ & Contrast \\
\hline 1000 & 168.8 & 1 & 1.06 & -0.01 & 1.08 \\
2000 & 606.6 & 11 & 2.20 & -0.22 & 2.42 \\
3000 & 1223.0 & 29 & 2.47 & -0.82 & 3.29 \\
$\mathbf{4 0 0 0}$ & $\mathbf{2 0 0 3 . 5}$ & $\mathbf{3 9}$ & $\mathbf{2 . 2 7}$ & $\mathbf{- 1 . 4 3}$ & $\mathbf{3 . 7 0}$ \\
5000 & 2880.7 & 40 & 1.92 & -1.49 & 3.41 \\
6000 & 3770.3 & 42 & 1.70 & -1.67 & 3.37 \\
7000 & 4739.9 & 42 & 1.47 & -1.62 & 3.09 \\
8000 & 5725.5 & 42 & 1.28 & -1.57 & 2.85 \\
9000 & 6729.0 & 42 & 1.12 & -1.51 & 2.63 \\
10000 & 7800.7 & 43 & 0.99 & -1.58 & 2.57 \\
$>10000$ & 24372.9 & 50 & & & \\
\hline
\end{tabular}

\section{Integrating patterns for epithermal gold model}

The patterns for three predictor themes are combined to form the epithermal gold deposit model. Table 7 summarizes the weights-of-evidence data for this model following integration of the predictor theme patterns. The contrast values indicate the strength of association of themes with the training set. Theme 1 was obtained from the categorical analysis for lithology and is included here only for comparative purposes. Themes 2, 3, and 4 are those used in the model. The lithology theme (theme 2) is the strongest predictor theme as indicated by its extremely high contrast value of 11.0. Its very strong $\mathrm{W}^{-}$of -8.4 (outside the pattern) indicates that unfavorable lithologic units are not associated with the training set. The high $\mathrm{W}^{+}$of 2.5 (inside the pattern) indicates that lithology is an extremely strong targeting pattern. The normal faults theme and placer gold theme (themes 3 and 4) are similarly characterized, however, their contrast values differ from the lithology pattern.

The integration of all patterns produces the weights-of-evidence model for the occurrence of undiscovered epithermal gold deposits. In this process, digital patterns are laid one upon another because they can be registered by cell addresses. A completed model expresses the additive results of predictor themes as a posterior probability map presented in the next section. This is the probability that a unit cell in the grid contains a training point after consideration of all predictor themes. This measurement changes from cell to cell depending on the values in cells of each predictor theme, being larger than the prior probability ${ }^{5}$ where the sum of weights is positive. The posterior probability is the sum of the prior probability and the cell-by-cell weights of the predictor themes (Raines, Bonham-Carter, and Kemp, 2000).

\footnotetext{
${ }^{5}$ Prior probability is the ratio of the number of training points to the area of the study area $(50 / 23600=.0021)$
} 
Table 7. Weights-of-evidence predictor theme data of epithermal gold model.

\begin{tabular}{|c|c|c|c|c|c|c|c|}
\hline Predictor theme & Criteria & Source & $\mathrm{W}^{+}$ & $\begin{array}{c}\text { Std. dev. } \\
\left(\mathrm{W}^{+}\right)\end{array}$ & $\mathrm{W}^{-}$ & $\begin{array}{l}\text { Std. dev. } \\
\left(\mathrm{W}^{-}\right)\end{array}$ & Contrast \\
\hline $\begin{array}{l}1 \text { Lithology } \\
\text { (categorical) }\end{array}$ & $\begin{array}{l}\text { Lithologic units } \\
\text { selected: Evkct, Eck, } \\
\text { Evkf, Evst, Evsf, Eco, } \\
\text { Eid, TRPMmsv }\end{array}$ & $\begin{array}{l}\text { Wash. DNR } \\
\text { geology }\end{array}$ & $\begin{array}{c}\text { ranges } \\
1.1 \text { to } \\
2.7\end{array}$ & $\begin{array}{c}\text { ranges } \\
0.58 \text { to } \\
0.18\end{array}$ & -8.1 & 10 & 10.8 \\
\hline $\begin{array}{l}2 \text { Lithology } \\
\text { (buffered, } \\
\text { cumulative) }\end{array}$ & $\begin{array}{l}0 \text { to } 150 \mathrm{~m} \text { of lithologic } \\
\text { units selected in theme } 1 \\
\text { (lithology) }\end{array}$ & $\begin{array}{l}\text { Wash. DNR } \\
\text { geology }\end{array}$ & 2.5 & 0.14 & -8.4 & 10 & 11 \\
\hline 3 Normal faults & $\begin{array}{l}0 \text { to } 1700 \mathrm{~m} \text { of } \\
\text { northwest-to-northeast- } \\
\text { trending normal faults }\end{array}$ & $\begin{array}{l}\text { Wash. DNR } \\
\text { geology }\end{array}$ & 1.4 & 0.14 & -3.6 & 1 & 5 \\
\hline 4 Placer gold & $\begin{array}{l}0 \text { to } 4000 \mathrm{~m} \text { of placer } \\
\text { sites }\end{array}$ & $\begin{array}{l}\text { USGS } \\
\text { MRDS and } \\
\text { MAS-MILS }\end{array}$ & 2.3 & 0.16 & -1.4 & 0.3 & 3.7 \\
\hline
\end{tabular}

\section{$\underline{\text { Tract definition }}$}

Tracts must be defined before attempting to interpret the posterior probability map. This paper adopts the approach that tracts may be defined as favorable, permissive, or nonpermissive to contain undiscovered epithermal gold deposits based on the probabilistic (posterior probability and other measures) data that extend over the study area. Defining the tracts involves an analysis of the geologic attributes that are characteristic for a given mineral deposit type. The foregoing validates the view that three predictor themes credibly express the characteristics of this deposit. The absence of a single critical characterizing attribute is sufficient to classify a tract as a "non-permissive" tract. In the past workers (Singer, 1993; Box and others 1996; Spanksi, written communication) have defined tracts as permissive or favorable for the occurrence of a mineral deposit in question. The terms relate closely to the descriptive model for these deposits as we have already discussed. The non-permissive tracts are those that are believed to have virtually no potential or only negligible potential for the occurrence of a deposit (Singer, 1993). Singer suggests this condition might equate to a deposit occurrence probability of less than one chance in 100,000 or 1,000,000. By defining non-permissive tracts in this way, the remaining unexcluded tracts may be defined as being permissive for the deposit type sought. Spanski (written commun.) refers to exclusionary criteria as passive criteria for delineation of deposits. Permissive areas are those where the geology permits the existence of deposits based on geologic criteria derived from descriptive models about deposits. It is becoming commonplace in conducting assessments to designate a subset of the permissive tracts as favorable tracts based on active criteria (Spanski, written commun.) where tracts possess a significantly higher potential for deposit occurrence. The approach followed here resembles this method, as follows: Low to mid-range probabilistic data define the non-permissive area (exclusionary criteria), high probabilities define the permissive terrane, and highest probabilities (active criteria) define the favorable tracts.

The posterior probability values, $\mathrm{P}$ (exclusionary and active criteria) essentially define the limits of the favorable, permissive, and non-permissive tracts for the epithermal gold model. The 
remaining probabilistic data from the weights-of-evidence analysis substantiate this conclusion. Table 8 shows the relationships of $\mathrm{P}$ to tracts following the integration step. The table contains eight classes corresponding to the number of possible combinations (inside, outside) for three predictor themes. $\mathrm{P}$ increases with number of training sites and sum of weights through the table. As viewed on cure on Figure 8, the $\mathrm{P}$ versus cumulative percent of the study area (fig. 8) provides a simple evaluation tool as the basis for separating the tracts on the posterior probability map (fig. 9). Table 8 provides the data to support this curve.

Criteria used in defining the favorable tracts (active criteria) are based on:

- Regions separated by natural breaks (inflection point) on the curve,

- Maintaining a consistent relationship between prior probability, p, (the known probability of the training sites) and the posterior probability, $\mathrm{P}$,

- Classes containing higher posterior probability values,

- Classes containing a larger number of training sites, and

- Classes containing predictor themes with highest contrast values,

The general method followed in applying these criteria is to limit the favorable area to a very small percentage (4.6\%) and the non-permissive area to a very large percentage of the study area. For permissive tracts, the same measures are applied, although at lowered limits. The nonpermissive tracts are those remaining after selection of the favorable and permissive tracts. The prior probability (0.0021) assists in defining tracts. Favorable tracts have posterior probability values greater than the prior probability, $\mathrm{p}$, the non-permissive tracts have posterior probability values less than $p$, and the permissive area lies somewhere in the middle ground.

Notable features on figure 8 are positions of curve inflection points that lie just below posterior probability values of 0.024 and 0.00016 . These prominent points tentatively establish the lower limits of the favorable and permissive areas, respectively (table 8) pending evaluation of other criteria. The non-permissive region falls below the lower inflection in the curve and represents 92 percent of the study area. The favorable region for this model, or 4.6 percent of the study area, lies above the upper inflection in the curve. The permissive region lies in the midrange area and represents 3.4 percent of the study area.

From the foregoing, classes 1 through 4 (table 8) define the non-permissive area. Classes 5 and 6 define the permissive area and contain the one remaining training site, Kettle. Classes 7 and 8 define the favorable area with the highest weights and highest posterior probabilities. The region of classes 7 and 8 includes the area with 49 or 50 of the training sites. At the upper end of the range, class 8 is most prospective and represents 0.6 percent $\left(154 \mathrm{~km}^{2}\right)$ of the map area. Class 8 corresponds to that area common to "inside the pattern" to all three predictor patterns; class 8 also has the highest posterior probability for containing undiscovered epithermal gold deposits.

The three-fold division can be further characterized by the coinciding relationships of predictor themes. The non-permissive tracts lack the lithology predictor pattern, a fatal flaw. The permissive tracts contain the lithology pattern, at a minimum; class 6 contains placer sites as an additional theme. The favorable tracts contain both the lithology and normal faults patterns, at minimum; class 8 contains all three patterns.

Due to the uncertainty in this model, the application of posterior probability values should not be strictly applied but should be limited to ranking tracts as non-permissive, permissive, or favorable. That is, it is unwise to apply the posterior probability values as actual probability values to express the potential for undiscovered deposits. 


\section{Posterior probability map}

The posterior probability map resulting from the integration process is shown in Figure 9. The colored areas represent the non-permissive (uncolored), permissive (blue), and favorable (red) tracts of the epithermal gold deposit model. The favorable and permissive areas largely fall within the area of the Republic and Toroda Creek Grabens corresponding to outcrops of Eocene volcanogenic rocks (compare fig. 4a and fig. 9). The uncolored areas are non-permissive tracts.

Table 8. Unique conditions data for epithermal gold deposit model.

${ }^{(1)}$ Buffered or cumulative weights theme for lithology ${ }^{(2)}$ Sum of weights is defined as the sum of weights of contributing themes from Table 7 (for example, class 7 equals sum of lithology [W+], normal faults $[\mathrm{W}+]$, and placer sites [W-], or $2.5+1.4+[-1.4]=2.5)$

\begin{tabular}{|c|c|c|c|c|c|c|c|c|c|c|}
\hline \multirow{2}{*}{$\stackrel{\Omega}{\tilde{0}}$} & \multirow{2}{*}{$\begin{array}{c}\text { Tract } \\
\text { definition }\end{array}$} & \multicolumn{3}{|c|}{ Patterns } & \multirow{2}{*}{$\begin{array}{l}\text { Train- } \\
\text { ing } \\
\text { sites }\end{array}$} & \multirow{2}{*}{$\begin{array}{l}\text { Area, } \\
\mathrm{km}^{2}\end{array}$} & \multirow{2}{*}{$\begin{array}{l}\text { Cumu- } \\
\text { lative } \\
\text { percent } \\
\text { area }\end{array}$} & \multirow{2}{*}{$\begin{array}{c}\text { Posterior } \\
\text { Probability }\end{array}$} & \multirow{2}{*}{$\begin{array}{l}\text { Sum of } \\
\text { weights } \\
(2)\end{array}$} & \multirow[t]{2}{*}{ Uncertainty } \\
\hline & & $\underset{\text { (1) }}{\text { Lithology }}$ & $\begin{array}{l}\text { Normal } \\
\text { faults }\end{array}$ & $\begin{array}{l}\text { Placer gold } \\
\text { sites }\end{array}$ & & & & & & \\
\hline 1 & \multirow{4}{*}{$\begin{array}{c}\text { Non- } \\
\text { permissive }\end{array}$} & Outside & Outside & Outside & 0 & 16,297 & $66.9 \%$ & 0.00000001 & -13.49 & 0.00000003 \\
\hline 2 & & Outside & Outside & Inside & 0 & 1103 & $71.4 \%$ & 0.00000011 & -9.79 & 0.00000115 \\
\hline 3 & & Outside & Inside & Outside & 0 & 4393 & $89.5 \%$ & 0.00000042 & -8.49 & 0.00000419 \\
\hline 4 & & Outside & Inside & Inside & 0 & 609 & $92.0 \%$ & 0.00001691 & -4.80 & 0.00016917 \\
\hline 5 & \multirow{2}{*}{ Permissive } & Inside & Outside & Outside & 1 & 695 & $94.8 \%$ & 0.00016703 & -2.51 & 0.00017765 \\
\hline 6 & & Inside & Outside & Inside & 0 & 139 & $95.4 \%$ & 0.00669556 & 1.18 & 0.00686940 \\
\hline 7 & \multirow{3}{*}{ Favorable } & Inside & Inside & Outside & 10 & 970 & $99.4 \%$ & 0.02400974 & 2.48 & 0.00914021 \\
\hline 8 & & Inside & Inside & Inside & 39 & 154 & $100.0 \%$ & 0.49815175 & 6.18 & 0.07388282 \\
\hline & & & & & 50 & 24,359 & & & & \\
\hline
\end{tabular}




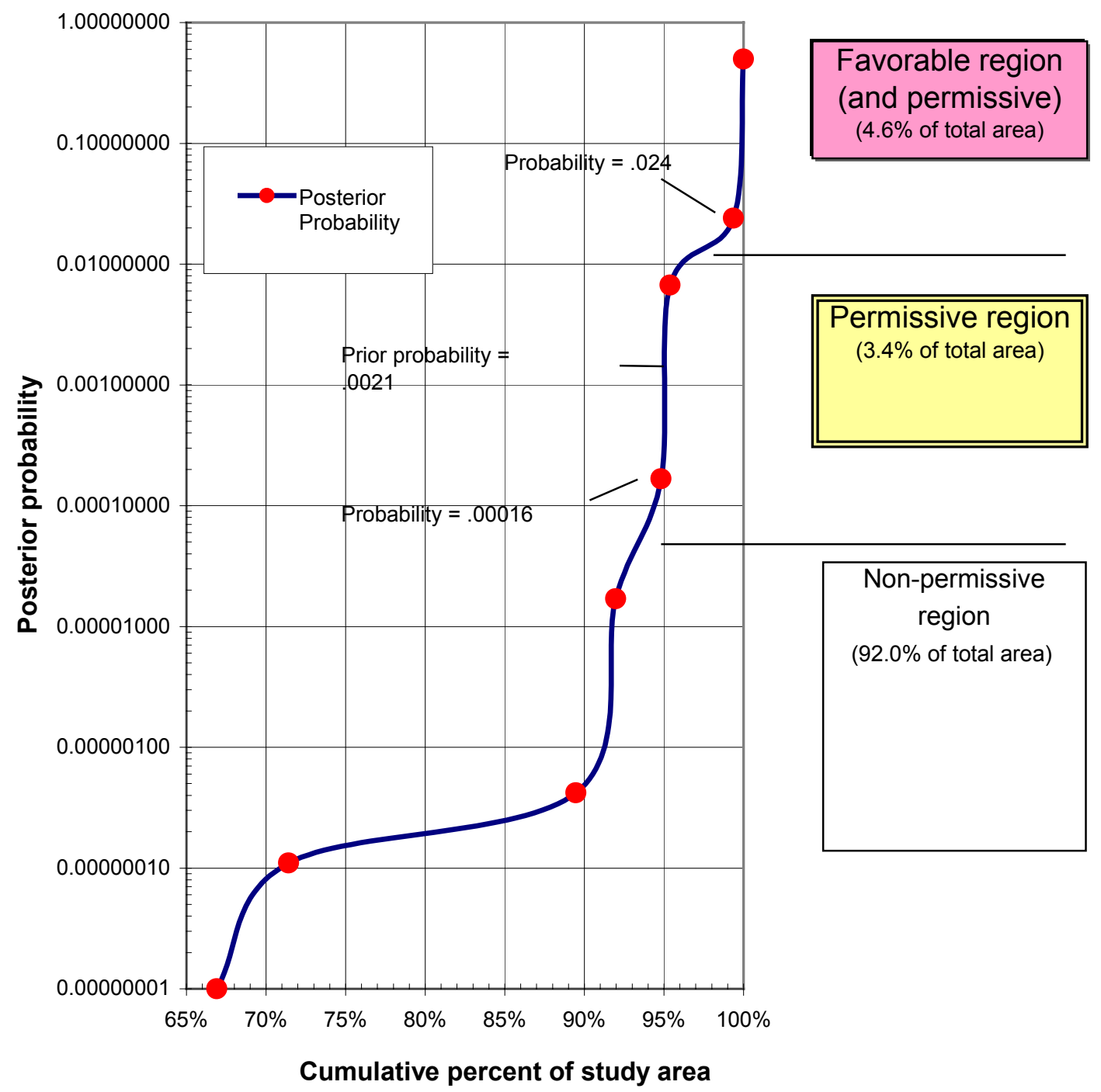

Figure 8. Probability results for epithermal gold deposit model.

Chart of posterior probability versus cumulative percent of study area for all unique conditions. The lower threshold of favorable region is assigned at 0.024 and includes 49 of 50 training sites. The lower threshold for the permissive region is arbitrarily assigned to 0.00016 and defines the class containing the prior probability. The prior probability is the known probability that the training set occurs in the study area. The permissive region also contains one training site, Kettle. 


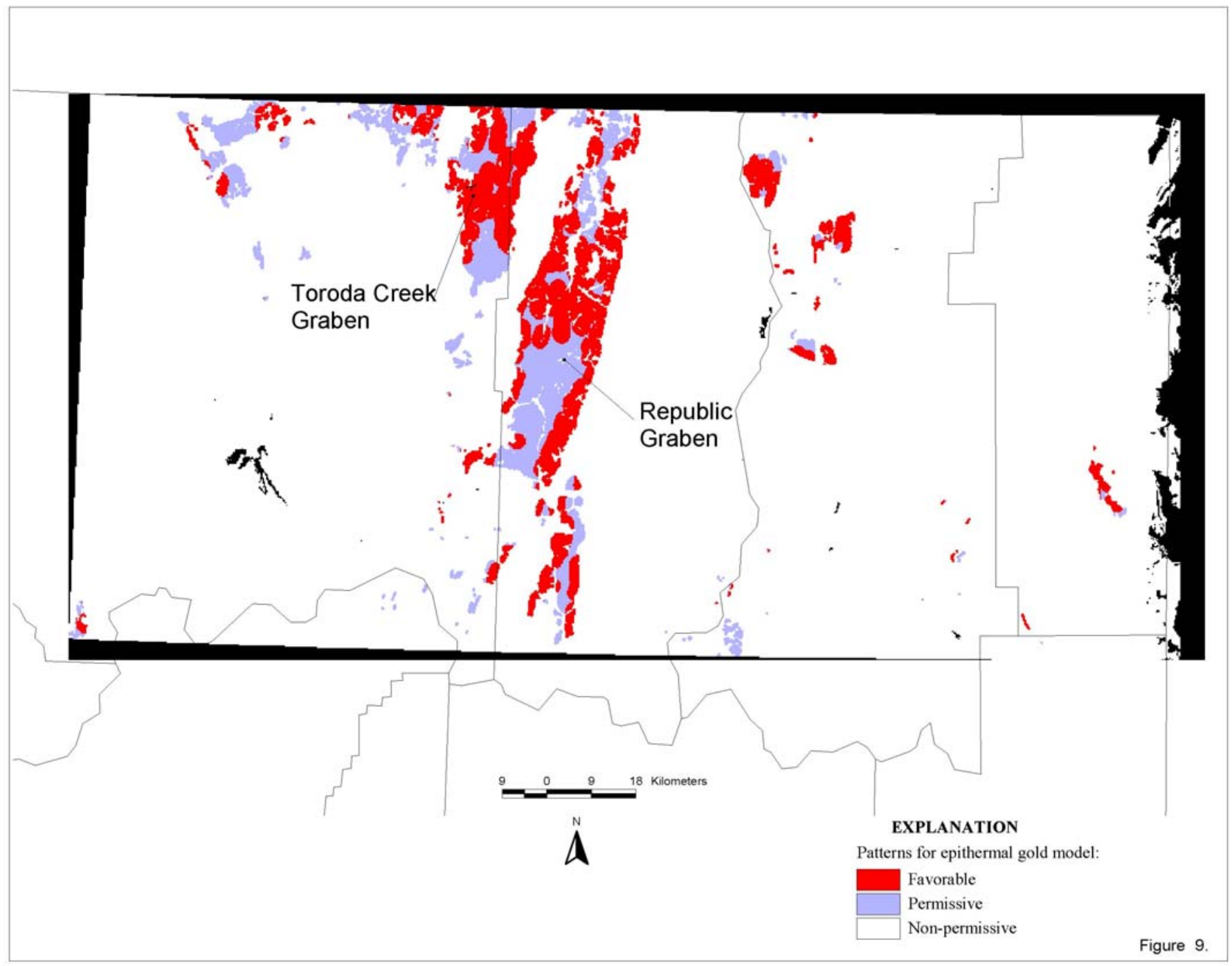

Figure 9. Map of epithermal gold deposit model showing favorable, permissive, and nonpermissive areas.

Red areas indicate favorable, blue areas indicate permissive, and uncolored area is non-permissive for discovery of undiscovered epithermal gold deposits. Black areas are artifacts of selecting a projected grid using a rectangular selection area. 


\section{MEASURES OF MINERAL ACTIVITY}

Mining claims are used to measure the level of industry exploration activity for epithermal gold deposits. Other activity data such as mineral permits on national forests are also appropriate to measure activity but are not used here. The digital mine claim records supplied by the Bureau of Land Management are utilized for the period of 1980 to 1996. Activity is assessed based on "snapshots" of mining claim records at the end of years 1980, 1985, 1990, and 1996 (Hyndman and Campbell, 1999). The choice of years was arbitrary. Digital data about mining claims became available after 1978 when BLM started to maintain digital records. The terms historic, current and consistent are introduced here to rank claimed areas for their relative importance to predict future activity.

Historic activity is defined as a section (one square mile) containing either (a) one or more mining claims in 1980 or (b) one or more valid mining claims in 1985 (fig. 10). Current activity is defined as having one or more valid lode mining claims in the section during either 1990 or 1996. Consistent activity is section qualifying for both historic and current activity (that is, at least one section for 1980 or 1985 and at least one section for 1990 or 1996). "None" indicates no claims were present or that the land may not be open to locating claims.

Figure 10 indicates the outline of the Republic and Toroda Creek grabens containing a checkerboard pattern of claimed sections. It also shows that the area of consistent claims activity (red) is widespread, although less extensive than the extent of historic activity shown in green. There are pockets of consistent activity located within the Republic Graben and along the Washington-British Columbia border. Color shading of a section indicates that at least one claim is present in the section. One claim occupies an area of 20.7 acres ( $8.5 \mathrm{ha})$.

There are disadvantages in using mining claims as an activity measure. It is known that the area of interest for gold in the vicinity of historic mines is largely private land. So, on private lands, the mining claims approach to predicting activity is not valid. Understandably, mining claims are silent as to the type of locatable mineral and mineral deposit sought. Since the purpose of this study was to provide an evaluation of epithermal gold on the Colville and Okanogan National Forests, the method is a reasonable approach if confined within the region containing Eocene volcaniclastic rocks. We looked at the nature of exploration based on annual reporting of activity to the Washington Department of Natural Resources over the 13-year period from 1985 through 1997 within the Republic, Toroda Creek, Keller, and First Thought grabens. These areas contain over $98 \%$ of Eocene volcaniclastic rocks. Exploration was conducted on 71 projects during the period and all were conducted for purposes of gold or gold-silver exploration or development. However, on 23 (32\%) of the 71 projects gold was sought in other than epithermal settings (Boleneus and Derkey, 2000). 


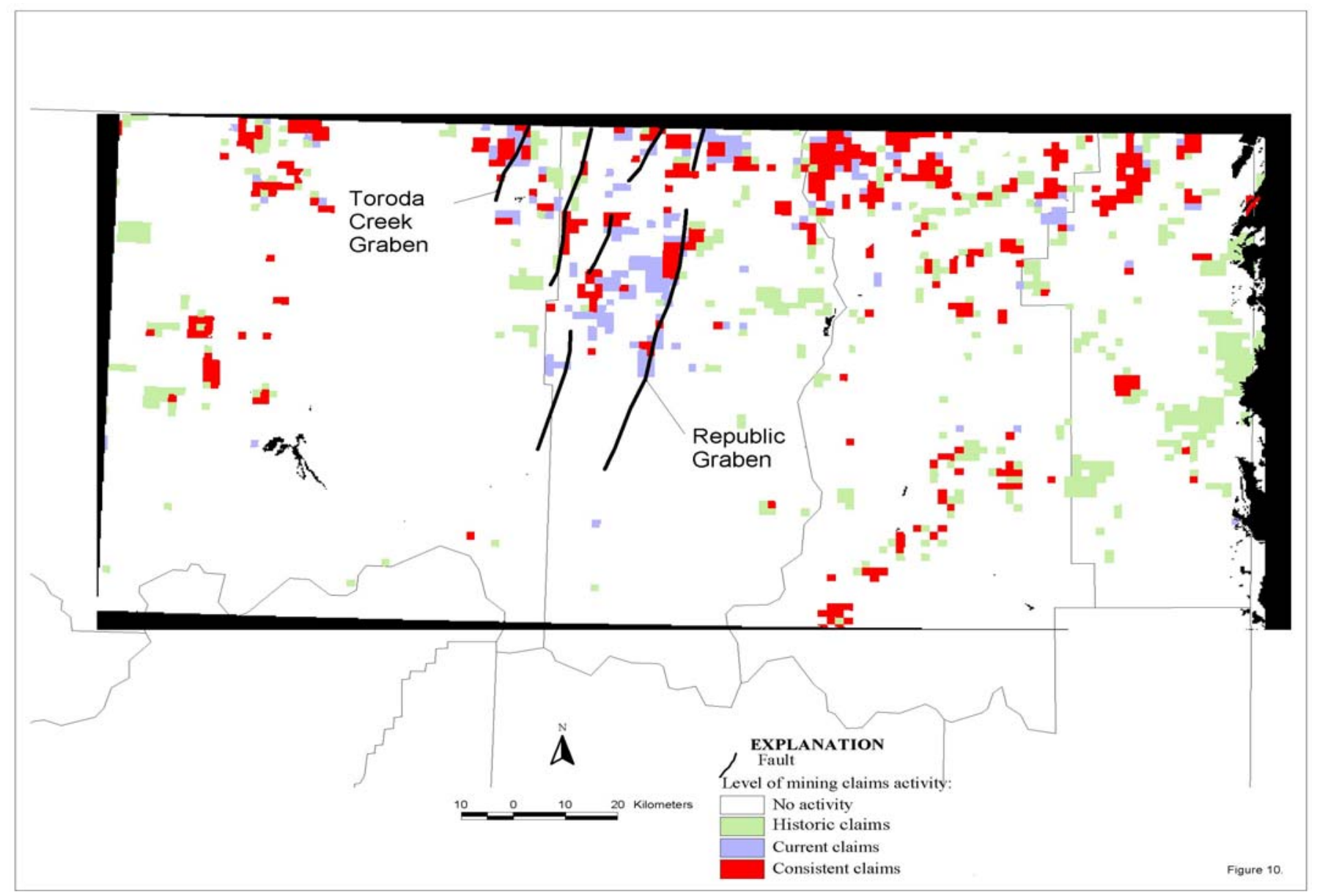

Figure 10. Historic, current, and consistent mining claims activity.

Color shading indicates one or more valid mining claim exists on a section during the period. Green represents a section containing historic claims. Purple indicates current claims. Red indicates consistent (both historic and current) claims. See text for explanation of these terms. 


\section{ASSESSMENT OF FUTURE MINERAL INDUSTRY ACTIVITY}

\section{Mineral resource-activity matrix}

A method is introduced here to relate the mining claims activity on federal lands to the deposit model for epithermal gold deposits. The purpose in investigating this relationship is to apply it as a land-management tool for federal land managers. The epithermal gold model is used as a measure of the undiscovered mineral resources and the mining claims are used as the measure of mineral industry exploration activity. The combination of the two data sets as called the assessment model for future exploration activity for gold deposits. The first step is to create a matrix to relate the two models, the mineral resource-activity matrix (fig. 11).

Taken together, the analysis of exploration activity and mining claim data are useful both as a predictor of future activity in seeking gold deposits and as a land management tool by federal land managers to assess the importance of minerals exploration activity on public lands. It is inconsequential to land managers that $32 \%$ of gold exploration is not for epithermal gold deposits. We assume that interest in exploration for epithermal gold deposits in the future will continue in areas known for past exploration activity.

The epithermal gold model has been divided into favorable, permissive, and nonpermissive categories. The mining claim activity model has been grouped into four categories of activity defined as historic, current, consistent, and none. These classes are combined into the matrix with five categories that address the interrelated nature of both models. The matrix communicates the potential for future mineral exploration activity of epithermal gold deposits, ranked as follows: no activity predicted, low activity, low to moderate activity, moderate activity, and high activity. The ranks are relative terms that relate the likelihood of an undiscovered deposit to exist in an area in relation to the historic and current levels of claim activity. We chose to use these five categories because we believe that the potential nine categories in this matrix subdivided the information more than the quality of the information warranted. The application of the matrix is, of course, specific to the deposit type being sought. Use of this assessment method enables forest plans or other land-use planning on public lands to incorporate mineral-related information where necessary.

\section{Assessment model}

The resource model-activity model matrix is employed to create the assessment model (fig. 12). The assessment model represents the level of mining claims activity on public lands modified by the resource model (epithermal gold model). Supporting data about the assessment model are provided in the unique conditions table (table 9). The high activity category (red) includes favorable areas having consistent or current mining claims activity. The moderate activity category (yellow) is defined as favorable areas with historic or no mining claims activity. The low-to-moderate (blue) category consists of permissive areas with consistent, current, or historic claims activity. The little or no activity category (low, green) consists of permissive areas with no activity predicted. 


\begin{tabular}{|c|c|c|c|c|c|c|}
\hline \multirow{3}{*}{$\begin{array}{c}\text { EPITHERAL } \\
\text { GOD } \\
\text { MODE }\end{array}$} & $p \geq .024$ & FAVORABLE & \multicolumn{2}{|c|}{$\begin{array}{l}\text { POTENIIALFOR } \\
\text { HIGHACIIVITY }\end{array}$} & $\begin{array}{l}\text { HIGHEST ACIIVTTY } \\
\text { EXPECTED }\end{array}$ & \multirow{4}{*}{$\begin{array}{c}\text { WTH } \\
\text { DRAWNor } \\
\text { NON } \\
\text { FEDERAL } \\
\text { MINERAL } \\
\text { ESTATE }\end{array}$} \\
\hline & $p \geq 0.000167$ & PERMSSIVE & $\begin{array}{l}\text { DTIIE } \\
\text { ORNO } \\
\text { ACIIVIT }\end{array}$ & \multicolumn{2}{|c|}{ LOWTOMODERATE ACIIVITY } & \\
\hline & & NON-PERMSSIVE & \multicolumn{3}{|c|}{ NOACIIVTY PREDICIED } & \\
\hline & & & NONE & HISTORIC & \begin{tabular}{l|l|l|} 
CURRENT & CONSISTENT \\
\end{tabular} & \\
\hline & & & \multicolumn{4}{|c|}{ ACTIVTY MODE } \\
\hline
\end{tabular}

Figure 11. Resource model-activity model matrix.

The matrix defines the interrelationship of the epithermal gold model and the mining claim activity model. Posterior probability (P) thresholds for the epithermal gold model are used to separate favorable, permissive, and non-permissive areas. Historic claims activity occurs on lands having valid claims in 1980 or 1985. Current claim activity occurs on lands having valid lode claims in 1990 or 1995. Consistent claims activity occurs on lands having land containing both current and historic claims. 


\section{$\underline{\text { Discussion }}$}

The locations of training sites are compared in the unique conditions of the assessment model (compare table 9, fig. 12). Seventeen of the training sites (classes 1, 5 in table 9) are located outside areas of current or historic activity and so these are likely located on private land holdings. Sixteen (class 5) of these sites are located within the favorable area based on the epithermal gold model. One site is located in class 1 that has little or no activity predicted. This site is the Kettle gold mine that is hosted by Eocene volcanic rocks. It occurs on private land but the deposit was buried beneath Quaternary deposits. About two-thirds, or 33 training sites (class 8) occur in the favorable epithermal gold model area associated with consistent mining claims activity. This indicates that about two-thirds of the favorable areas occur on lands that are both subject to location of mining claims and are of highest interest.

In comparing figures 9 (epithermal gold model) and 12 (assessment model) the favorable areas for the epithermal gold deposit model are subdivided into moderate activity and high activity areas on the map for the assessment model. That is, the yellow (class 5,6) and red (class 7,8 ) areas on the assessment map occupy the same as the red areas on the epithermal gold model map. Likewise the green (class -1,0) and blue (class 1) areas on the assessment model map are subdivisions of the purple areas on the epithermal gold model map.

Table 9. Unique conditions data for assessment model.

\begin{tabular}{|c|c|c|c|c|c|c|}
\hline \multicolumn{2}{|c|}{ Mining claims activity } & \multirow{2}{*}{$\begin{array}{c}\text { Epithermal gold } \\
\text { model }\end{array}$} & \multicolumn{2}{|r|}{ Assessment model } & \multirow{2}{*}{$\begin{array}{l}\text { Training } \\
\text { sites }\end{array}$} & \multirow{2}{*}{$\begin{array}{l}\text { Area, } \\
\mathrm{km}^{2}\end{array}$} \\
\hline Historic & Current & & Class & Category & & \\
\hline Outside & Outside & -- & -1 & Unknown & 0 & 12 \\
\hline Inside & Outside & -- & -1 & Unknown & 0 & 1 \\
\hline Inside & Inside & -- & -1 & Unknown & 0 & $<1$ \\
\hline Outside & Inside & -- & -1 & Unknown & 0 & $<1$ \\
\hline-- & -- & -- & -1 & Unknown & 0 & $<1$ \\
\hline Outside & Outside & Non-permissive & 0 & No activity predicted & 0 & 20,187 \\
\hline Inside & Outside & Non-permissive & 0 & No activity predicted & 0 & 1,096 \\
\hline-- & -- & Non-permissive & 0 & No activity predicted & 0 & 3 \\
\hline Inside & Inside & Non-permissive & 0 & No activity predicted & 0 & 834 \\
\hline Outside & Inside & Non-permissive & 0 & No activity predicted & 0 & 281 \\
\hline Outside & Outside & Permissive & 1 & Little or no activity & 1 & 705 \\
\hline Inside & Outside & Permissive & 2 & Low to moderate activity & 0 & 47 \\
\hline Outside & Inside & Permissive & 3 & Low to moderate activity & 0 & 38 \\
\hline Inside & Inside & Permissive & 4 & Low to moderate activity & 0 & 44 \\
\hline Outside & Outside & Favorable & 5 & Moderate activity & 16 & 783 \\
\hline Inside & Outside & Favorable & 6 & Moderate activity & 0 & 57 \\
\hline Outside & Inside & Favorable & 7 & High activity & 0 & 143 \\
\hline \multirow[t]{2}{*}{ Inside } & Inside & Favorable & 8 & High activity & 33 & 141 \\
\hline & & & & & 50 & 24,373 \\
\hline
\end{tabular}




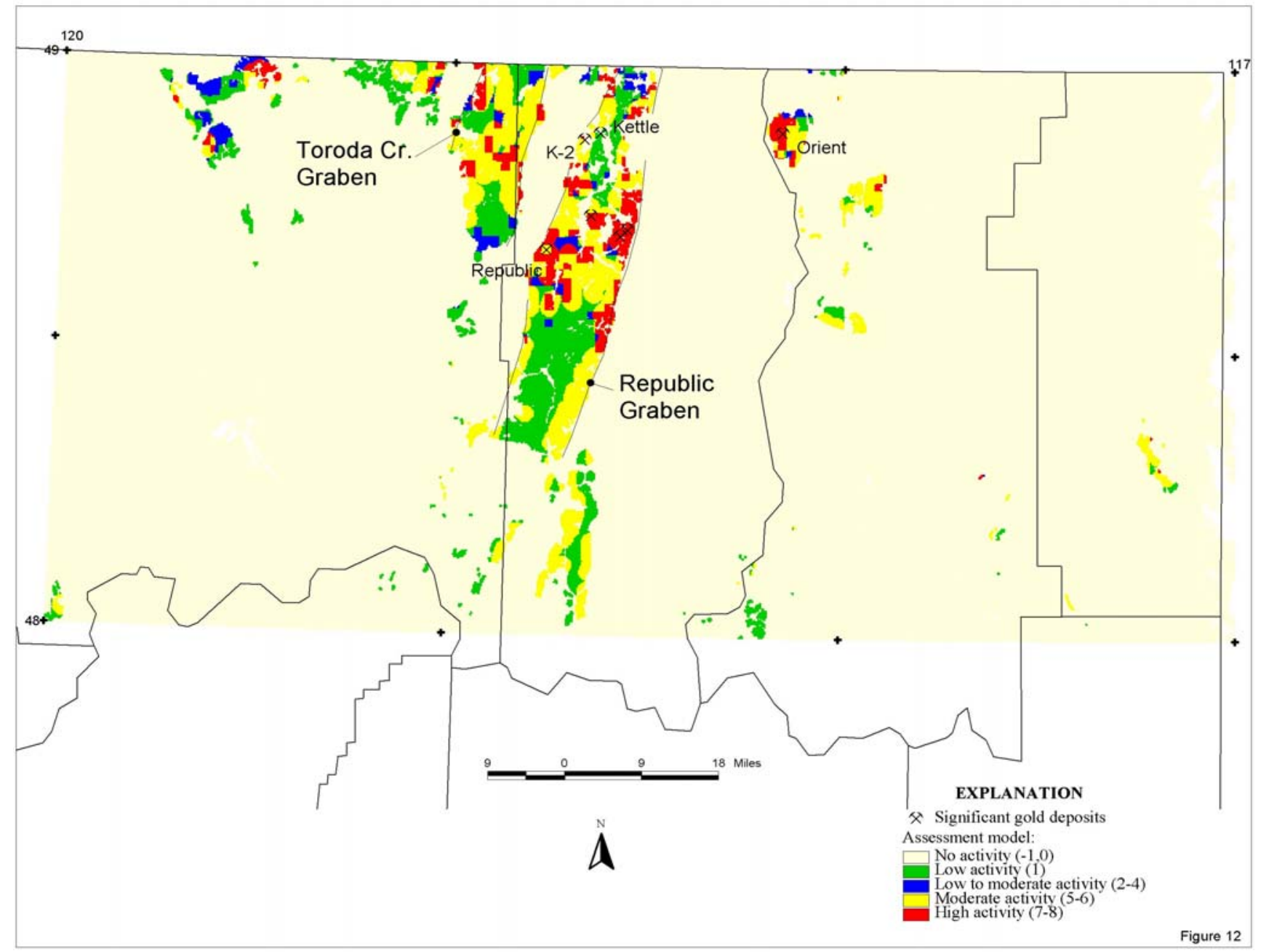

Figure 12. Map of assessment model.

This model consists of combined models for mining claim activity and epithermal gold. Numbers in parentheses refer classes defined in the table. Mine symbols that are named are significant epithermal gold deposits (Long, DeYoung, and Ludington, 1998). Unlabeled mine symbols are gold deposits of another type. 


\section{CONCLUSIONS}

Hypothesis testing methods of the weights-of-evidence analysis were carried out on a number of specifically prepared digital geological themes for the evaluation of epithermal gold deposits in a $222 \mathrm{~km} \mathrm{x} 277 \mathrm{~km}$ area of northeastern Washington State. A training set consists of 50 epithermal gold mines and prospects. A geologic map theme contained sub-sets consisting of lithologic units, faults, and folds. Geochemistry data included 67 placer gold sites.

The three themes describe the spatial correlation with the training set and are selected as the predictor themes during the analysis. They include the lithologic units theme, NW-to-NNE normal faults theme, and placer gold sites theme. The lithologic units pattern includes eight map units surrounded by a $150-\mathrm{m}$ buffer. This theme areally describes the Klondike Mountain Formation and Sanpoil Volcanics, with known associations with epithermal gold deposits. The normal faults theme is a sub-set of normal faults having orientations that ranging from $345^{\circ}-30^{\circ}$. This pattern includes the NW-NNE-oriented normal faults surrounded by a $1700-\mathrm{m}$ buffer. The pattern for placer gold sites includes these sites surrounded by a $4000-\mathrm{m}$ buffer. The epithermal gold model is formed by the integration (or overlayment) of these predictor themes. The probabilistic results of this model (1) describe the likelihood for occurrence of epithermal gold deposits and (2) form the basis for subdividing tracts into favorable, permissive, and nonpermissive tracts according the grid cell-by grid cell presence of each predictor theme on the map. Favorable tracts were limited by posterior probability values $(\mathrm{P})>0.024$. This area also contained 49 of 50 training sites and covers 4.6 percent of the study area. The favorable area is restricted to the Republic, Toroda Creek, and Keller grabens, or areas of outcropping Eocene Klondike Mountain Formation and Sanpoil Volcanics. Permissive tracts represent another 3.4 percent of the study area where $\mathrm{P}>0.00016$. Non-permissive tracts ( 92 percent) had $\mathrm{P}<0.00016$. Other probabilistic data (patterns, $p$, sum of weights) assisted to define tracts.

Mining claim activity is defined by the locations of lode mining claims summarized for the years, 1980, 1985, 1990, and 1996. Terms defined here, historic, current, or consistent parcels, defined longevity and occurrence of mining claims during combinations of these years.

A matrix describing the interaction of the resource model-mining claim activity was defined to accommodate both the mining claim activity (historic, current, and consistent) and the occurrence for the epithermal gold deposits (favorable, permissive, and non-permissive). This combination describes the assessment model for gold deposits on public lands.

The assessment model represents the level of mining claims activity on public lands modified by the resource model (epithermal gold model) and assists federal land managers in land use decision-making by providing a prediction of mineral exploration activity in the next decade. The first category is high activity category which includes favorable tracts having consistent or current mining claims activity The moderate activity category is defined as favorable tracts with historic or no mining claims activity. The low-to-moderate category consists of permissive tracts with consistent, current, or historic claims activity. The little or no activity category is permissive tracts with no activity predicted. The assessment model cannot be applied to lands other than public lands since mining claims are only staked on public lands. The model cannot be strictly considered for epithermal gold deposits because 32 percent ( 23 of 71 projects) of exploration and development projects occurring in the area of Republic, Toroda Creek, and Keller grabens during the 1985 through 1997 targeted gold in other than epithermal gold settings. 


\section{REFERENCES CiTED}

Berger, B.R., 1986, Descriptive model hot spring Au-Ag, in Mineral Deposit Models (Cox, D.P. and Singer, D.A., Eds.): U.S. Geological Survey Bulletin 1693, p. 143-144.

Boleneus, D.E., 1999a, Geologic datasets for weights-of-evidence analysis in Northeast Washington-2. Mineral databases: U.S. Geological Survey Open-File Report 99-384, 33p. http://geopubs.wr.usgs.gov/open-file/of99-384

-----1999b, Geologic datasets for weights-of-evidence analysis in Northeast Washington-3. Minerals-related permits on national forests, 1967 to 1998: U.S. Geological Survey Open-File Report 99-414, 32p. http://wrgis.wr.usgs.gov/open-file/of99-414/of99-414

and Chase, D.W., 1999, Digital analytical data from mineral resource assessments of National Forest lands in Washington: U.S. Geological Survey Open-File Report 99-344, 68 p. http://wrgis.wr.usgs.gov/open-file/of99-384/

Boleneus, D.E. and Causey, J.D., 2000, Geologic data sets for weights-of-evidence analysis in northeast Washington-1. Geologic raster data: U.S. Geological Survey Open-File Report 00-495, 33 p. http://geopubs.wr.usgs.gov/open-file/of00-495/

Boleneus, D.E. and Derkey, R.F., 2000, Geologic datasets for weights-of-evidence analysis in northeast Washington - 4. Mineral industry activity in Washington, 1985-1997: U.S. Geological Survey Open-File Report 00-014, 68 p. http://geopubs.wr.usgs.gov/open-file/of00-014

Bonham-Carter, G.F., 1994, Geographic Information Systems for Geoscientists--Modeling with GIS: Pergamon, Oxford, 398 p.

Bonham-Carter, G.F., Agterberg, F.P. and Wright, D.F., 1988, Integration of geological datasets for gold exploration in Nova Scotia: Photogrammetric Eng. and Remote Sensing, v. 54, no. 11, pp 1585-1592.

Box, S.E., 1994, Detachment origin for Republic graben, northeastern Washington, in Regional Geology of Washington State (Lasmanis, R., and Cheney, E. editors): Washington Division of Geology and Earth Resources, Bull. 80, p. 223.

----- Bookstrom, A.A., Zientek, M.L., Derkey, P.D., Ashley, R.P., Elliot, J.E., and Peters, S.E., 1996, Assessment of undiscovered mineral resources in the Pacific Northwest-a contribution to the interior Columbia River Basin ecosystem management project: U.S. Geological Survey Open-File Report 95-682, 282 p., 4 app.

Buchanan, L.J., 1981, Precious metal deposits associated with volcanic environments in the southwest: Arizona Geological Society Digest, v. 14, p. 237-261. 
Derkey, R.F., 1995, The metallic mining industry of Washington in 1994: Washington Geology, Washington State Department of Natural Resources, Olympia, Wash., v. 23, p. 3-19.

1996, The metallic, nonmetallic, and industrial mineral industry of Washington in 1995:

Washington Geology, Washington State Department of Natural Resources, Olympia, Wash, v. 24, p. 3-19.

---- 1997, The metallic, nonmetallic, and industrial mineral industry of Washington in 1996: Washington Geology, Washington State Department of Natural Resources, Olympia, Wash., v. 25, p. 3-11.

1998, The metallic, nonmetallic, and industrial mineral industry of Washington-1997: Washington Geology, Washington State Department of Natural Resources, Olympia, Wash., v. 26, p. 3-10.

Derkey, R.F. and C. Gulick, 1992, Washington's mineral industry—1991: Washington Geology, Washington State Department of Natural Resources, Olympia, Wash., v. 20, p. 3-25.

1994, Metallic mineral deposits: Washington Geology, Washington State Department of Natural Resources, Olympia, Wash., v. 22, p. 16-18.

Derkey, R.F., Gulick, C., and Lingley, W.S., 1993, Washington's mineral industry—1992: Washington Geology, Washington State Department of Natural Resources, Olympia, Wash., v. 21, p. 3-30.

Fifarek, R.H., Devlin, B.D., and Tschauder, Jr. R.J., 1996, Au-Ag mineralization at the Golden Promise deposits, Republic district, Washington-Relation to graben development and hot spring processes, in Coyner, A.R. and Fahey, P.L., (eds.), Geology and Ore Deposits of the American Cordillera: Geological Society of Nevada Symposium Proceedings, Reno, Nevada, April 1995, p. 1063-1088.

Fox, K.F. Jr., 1994, Geology of metamorphic core complexes and associated extensional structures in north-central Washington, in Regional Geology of Washington State (Lasmanis, R., and Cheney, E. Eds.): Washington Division of Geology and Earth Resources, Bull. 80, p. 49-72.

Full, R. P. and Grantham, R.M., 1968, Ore deposits of the Republic Mining District, Ferry County, Washington, in J.D. Ridge, Ed., Ore deposits of the United States, 1933-1967: American Inst. of Mining, Metallurgical and Petroleum Engineers, New York, p. 1481-1494.

Gulick, C.W. and Korosec, M.A., 1990, Geologic map of the Omak 1:100,000 quadrangle, Washington: Washington Department of Natural Resources, Open File Report 90-12, $52 \mathrm{p}$.

Hyndman, P.C. and Campbell, H. C., 1999, Digital databases containing mining claim density 
information for Arizona, California, Colorado, Idaho, Montana, Nebraska, New Mexico, Nevada, Oregon, South Dakota, Utah, Washington, and Wyoming created from the BLM mining claim recordation systems, 1996: U.S. Geological Survey Open-File Report 99-325, $21 \mathrm{p}$.

Joseph, N.L., 1990a, Geologic map of the Colville 1:100,000 quadrangle, Washington: Washington Department of Natural Resources, Open File Report 90-13, 78 p.

1990b, Geologic map of the Nespelem 1:100,000 quadrangle, Washington: Washington Department of Natural Resources, Open File Report 90-16, 47 p.

----- 1990c, Washington's mineral industry in 1989: Washington Geology, Washington State Department of Natural Resources, Olympia, WA, v. 18, p. 3-22.

----- 1991, Washington's mineral industry-1990: Washington Geology, Washington State Department of Natural Resources, Olympia, WA, v. 19, p. 3-24.

Kemp, L.D., Bonham-Carter, G.F. and Raines, G.L., 1999, Arc-WofE: Arcview extension for weights-of-evidence mapping: Geological Survey of Canada, Users guide, $76 \mathrm{pp}$. http://gis.nrcan.gc.ca/software/arcview/wofe

Landes, H.R., Roberts, M., and Lyon, D.A., 1902, The metalliferous resources of Washington, except iron: Washington Geological Survey 1, pp.39-157.

Long, K.R., 1992, Preliminary descriptive model for detachment-fault-related mineralization: U.S. Geological Survey Bulletin 2004, p. 52-58.

DeYoung, J.H., Jr., and Ludington, S.D., 1998, Database of significant deposits of gold, silver, copper, lead, and zinc in the United States, in Part A, Database description and analysis; Part B, Database: U.S. Geological Survey Open-File Report 98-206A, 33p.

Mihalasky, M.J., 1999, Mineral potential modeling of gold and silver mineralization in the Nevada Great Basin: Ph.D. Dissertation, University of Ottawa, 354 p.

Mosier, D., Singer, D. and Berger, B., 1986, Descriptive model for Comstock epithermal veins, in Mineral deposit models (D. Cox and D. Singer, Eds.): U.S. Geological Survey Bulletin 1693, p. 150.

Mosier, D., Sato, T., Page, N., Singer, D. and Berger, B., 1986, Descriptive model of Creede epithermal veins, in Mineral deposit models (D. Cox and D. Singer, Eds.): U.S. Geological Survey Bulletin 1693, p. 145-146.

Muessig, S., 1967, Geology of the Republic Quadrangle and a part of the Aeneas Quadrangle, Ferry County, Washington: U. S. Geological Survey Bulletin, Report: B 1216, 135 pp.

Pearson, R.C. and Obradovich, J.D., 1977, Eocene rocks in Northeast Washington; radiometric ages and correlation: U. S. Geological Survey Bulletin, Report: B 1433, 41 pp. 
Raines, G.L., 1999, Evaluation of weights of evidence to predict epithermal-gold deposits in the Great Basin of the western United States: Natural Resources Research, v. 8, no. 4, p. 257-276.

Raines, G.L., Bonham-Carter, G.F., and Kemp, L., 2000, Predictive probabilistic modeling using ArcView GIS: ArcUser, Environmental Systems Research Institute, Inc., Redlands, Calif., April-June, vol. 2 no. 2., p 45-48, http://esri.com/news/arcuser/0400/files/wofe.pdf

Siegel, S., 1956, Non-parametric statistics in the behavioral sciences: McGraw-Hill Book Co., $321 \mathrm{p}$.

Singer, D.A., 1993, Basic concepts in three-part quantitative assessment of undiscovered mineral resources: Nonrenewable Resources, Oxford University Press, v. 2, no. 2, p. 69-81.

Stoffel, K.L., 1990a, Geologic map of the Oroville 1:100,000 quadrangle, Washington: Washington Department of Natural Resources, Open File Report 90-11, 58 p.

----- 1990b Geologic map of the Republic 1:100,000 quadrangle, Washington: Washington Department of Natural Resources Open File Report 90-10, 62 p.

Stoffel, K.L., Joseph, N.L., Waggoner, S.Z., Gulick, C.W., Korosec, M.A., and Bunning, B.B., 1991, Geologic map of Washington, northeast quadrant: Geologic map GM-39, Washington Department of Natural Resources. 2 sheets.

Tschauder, Jr., R.J., 1989, Gold deposits in northern Ferry County, Washington, in Joseph, N.L., and others, Eds., Geologic guidebook for Washington and adjacent areas: Washington Division of Geology and earth Resources, Information Circular 86, p. 241-253.

USBM, 1995, MAS/MILS (Mineral Availability System/Mineral Industry Location System) CD-ROM: US Bureau of Mines Special Publication 12-95, http://minerals.usgs.gov/minerals/pubs/

USGS, Mineral Resource Data System database: U.S. Geological Survey, CD-ROM http://edcwww.cr.usgs.gov/Webglis/glisbin/guide.pl/glis/hyper/guide/mrds/.

Waggoner, S.Z, 1992, Geologic map of the Chewelah 1:100,000 quadrangle, Washington-Idaho: Washington Department of Natural Resources, Open File Report 90-14, 63 p.

Wright, D.F. and Bonham-Carter, G.F., 1996, VHMS favourability mapping with GIS-based integration models, Chisel Lake-Anderson Lake area, in EXTECH I--A Multidisciplinary Approach to Massive Sulphide Research in the Rusty Lake-Snow Lake Greenstone Belts, Manitoba (Bonham-Carter, G.F., Galley, A.G., and Hall, G.E.M., Eds.): Geological Survey of Canada, Bulletin 426, p. 339-401. 


\section{APPENDIX}

\section{Appendix I. Databases}

\section{A. Training set for epithermal gold}

\begin{tabular}{|c|c|c|c|c|c|c|c|}
\hline Site name & $\begin{array}{l}\text { MRDS Identifier } \\
\text { number }\end{array}$ & $\begin{array}{l}\text { MAS Identifier } \\
\text { number. }\end{array}$ & Latitude & Longitude & $\begin{array}{l}\text { USGS } \\
\text { Model }^{1}\end{array}$ & Production size & $\begin{array}{l}\text { Posterior } \\
\text { probability }\end{array}$ \\
\hline 1 Admiral & M056000 & & 48.6600 & -118.7369 & $25 \mathrm{a}$ & No production & 0.0932 \\
\hline 2 Advance & M056001 & & 48.6267 & -118.7453 & $25 \mathrm{a}$ & No production & 0.0932 \\
\hline 3 Alpine & M056023 & & 48.6767 & -118.7578 & $25 \mathrm{a}$ & No production & 0.0932 \\
\hline 4 Anecia & M056024 & & 48.6619 & -118.7803 & $25 \mathrm{a}$ & No production & 0.0932 \\
\hline 5 Ben Hur & SP00062 & & 48.6686 & -118.7581 & $25 \mathrm{c}$ & Small & 0.0932 \\
\hline 6 Blacktail (Hope) & SP00063 & & 48.6633 & -118.7475 & $25 \mathrm{c}$ & Small & 0.0932 \\
\hline 7 Bodie & M056027 & & 48.6606 & -118.7572 & $25 \mathrm{a}$ & No production & 0.0932 \\
\hline 8 Cook & M056029 & & 48.6372 & -118.7536 & $25 \mathrm{a}$ & No production & 0.0932 \\
\hline 9 East Sanpoil & M056030 & & 48.6614 & -118.7572 & $25 \mathrm{a}$ & No production & 0.0932 \\
\hline 10 El Caliph & M056031, SP00068 & & 48.6592 & -118.7639 & $25 \mathrm{c}$ & Small & 0.0932 \\
\hline 11 Flag Hill & M056032, SP00069 & & 48.6522 & -118.7536 & $25 \mathrm{c}$ & No production & 0.0932 \\
\hline 12 Golden Eagle & M056004 & & 48.6600 & -118.7369 & $25 \mathrm{a}$ & No production & 0.0932 \\
\hline 13 Ida May & SP00075 & & 48.6547 & -118.7647 & $25 \mathrm{c}$ & No production & 0.0932 \\
\hline 14 Insurgent & SP00076 & & 48.6669 & -118.7461 & $25 \mathrm{c}$ & Small & 0.0932 \\
\hline 15 Iron Mask & M056033 & & 48.6561 & -118.7544 & $25 \mathrm{a}$ & No production & 0.0932 \\
\hline 16 Iron Mountain & M056123 & & 48.5639 & -118.5994 & $25 \mathrm{a}$ & No production & 0.0932 \\
\hline 17 Jim Blaine Fraction & M056009 & & 48.6328 & -118.7453 & $25 \mathrm{a}$ & No production & 0.0932 \\
\hline 18 K2 Mine $^{2}$ & na & 0530190470 & 48.8660 & -118.6680 & $25 \mathrm{a}$ & Large & 0.0932 \\
\hline 19 Kangaroo & M056034 & & 48.6614 & -118.7572 & $25 \mathrm{a}$ & No production & 0.0932 \\
\hline 20 Kettle & SP00080 & & 48.8789 & -118.6256 & $25 \mathrm{a}$ & Large & 0.0007 \\
\hline $\begin{array}{l}21 \text { Knob Hill mine and } \\
\text { plant }\end{array}$ & na & 0530190084 & 48.6734 & -118.7578 & $25 \mathrm{c}$ & Large & 0.0932 \\
\hline 22 Last Chance & $\begin{array}{l}\text { M056010, D001629, } \\
\text { SP0008 }\end{array}$ & & 48.6658 & -118.7458 & $25 \mathrm{a}$ & Small & 0.0932 \\
\hline 23 Little Cove & M056036, SP00085 & & 48.6669 & -118.7533 & $25 \mathrm{c}$ & Small & 0.0932 \\
\hline 24 Lone Pine & M056037, SP00086 & & 48.6653 & -118.7506 & $25 \mathrm{c}$ & Moderate & 0.0932 \\
\hline 25 Mammoth & M056011 & & 48.6725 & -118.7428 & $25 \mathrm{a}$ & No production & 0.0932 \\
\hline 26 Mountain Lion & M056039 SP00095 & & 48.6789 & -118.7686 & $25 \mathrm{c}$ & Small & 0.0932 \\
\hline 27 North Sanpoil & SP00096, M056012 & & 48.6667 & -118.7586 & $25 \mathrm{c}$ & Small & 0.0932 \\
\hline 28 Old Hickory & SP00097, M056013 & & 48.6392 & -118.7428 & $25 \mathrm{c}$ & No production & 0.0932 \\
\hline 29 Pearl & M056040, SP00100 & & 48.6669 & -118.7533 & $25 \mathrm{c}$ & No production & 0.0932 \\
\hline $\begin{array}{l}30 \text { Princess Maude } \\
\text { (Southern Republic) }\end{array}$ & SP00102 & & 48.6347 & -118.7475 & $25 \mathrm{c}$ & Small & 0.0932 \\
\hline
\end{tabular}




\section{A. Training set for epithermal gold (cont.)}

\begin{tabular}{|c|c|}
\hline $\begin{array}{l}31 \text { Quilp (Imperator, } \\
\text { Eureka) }\end{array}$ & M056016 \\
\hline 32 Rebate & M056041 \\
\hline $\begin{array}{l}33 \text { Republic (Blaine } \\
\text { Republic) }\end{array}$ & SP00104 \\
\hline 34 Sanpoil Fraction & $\begin{array}{l}\text { M056043, M056042, } \\
\text { SP0010 }\end{array}$ \\
\hline 35 Seattle & M056044, SP00107 \\
\hline 36 Snowstorm & M056045 \\
\hline 37 South Penn & SP00112, M056046 \\
\hline 38 Standard and Emma & M056018 \\
\hline 39 Surprise & SP00114, M056019 \\
\hline 40 Tom Thumb & SP00117, M056047 \\
\hline 41 Trade Dollar & M056048, SP00118 \\
\hline $42 \mathrm{~V}$ Fraction & M056021 \\
\hline 43 Zalla M & M056126, SP00122 \\
\hline 44 American Flag & SP00186 \\
\hline $\begin{array}{l}45 \text { Bodie Mountain } \\
\text { Mine (Northern } \\
\text { Gold) }\end{array}$ & M056791 \\
\hline $\begin{array}{l}46 \text { Sheridan (Phil } \\
\text { Sheridan) }\end{array}$ & SP00283 \\
\hline 47 Silver Bell & SP00285 \\
\hline 48 First Thought Mine & M060170, M056476 \\
\hline 49 Hidden Treasure & M056495 \\
\hline 50 Nest Egg & M056501 \\
\hline
\end{tabular}

\begin{tabular}{|c|c|c|c|c|}
\hline 48.6561 & -118.7475 & $25 c$ & Small & 0.0932 \\
\hline 48.6939 & -118.7542 & $25 \mathrm{a}$ & No production & 0.0932 \\
\hline 48.6375 & -118.7453 & $25 \mathrm{c}$ & Small & 0.0932 \\
\hline 48.6669 & -118.7533 & $25 \mathrm{a}$ & Small & 0.0932 \\
\hline 48.6642 & -118.7669 & $25 \mathrm{c}$ & No production & 0.0932 \\
\hline 48.6614 & -118.7572 & $25 \mathrm{a}$ & No production & 0.0932 \\
\hline 48.6903 & -118.7558 & $25 \mathrm{c}$ & Small & 0.0932 \\
\hline 48.6306 & -118.7461 & $25 \mathrm{a}$ & No production & 0.0932 \\
\hline 48.6608 & -118.7492 & $25 \mathrm{c}$ & Small & 0.0932 \\
\hline 48.6961 & -118.7572 & $25 \mathrm{c}$ & Small & 0.0932 \\
\hline 48.6733 & -118.7508 & $25 \mathrm{c}$ & No production & 0.0932 \\
\hline 48.6658 & -118.7458 & $25 \mathrm{a}$ & No production & 0.0932 \\
\hline 48.7667 & -118.8314 & $25 b$ & Small & 0.0932 \\
\hline 48.7536 & -118.8453 & $25 b$ & No production & 0.0932 \\
\hline 48.8158 & -118.9036 & $25 \mathrm{a}$ & Small & 0.0932 \\
\hline 48.7786 & -118.8547 & $25 \mathrm{a}$ & Small & 0.0932 \\
\hline 48.7597 & -118.8383 & $25 b$ & Small & 0.0932 \\
\hline 48.8839 & -118.1611 & $25 \mathrm{c}$ & Small & 0.0932 \\
\hline 48.8739 & -118.1656 & $25 \mathrm{a}$ & No production & 0.0932 \\
\hline 48.8481 & -118.1586 & $25 \mathrm{a}$ & No production & 0.0932 \\
\hline
\end{tabular}

${ }^{1}$ Hot spring Au-Ag (25a); Creede epithermal veins (25b); Comstock epithermal veins (25c) ; ${ }^{2}$ Long, DeYoung, and Ludington, 1998; ( .) - alternate name; na - none available 


\section{B. Placer sites}

[na none available; ${ }^{1}$ located in Washington except those in Boundary County]

\begin{tabular}{|c|c|c|c|c|c|}
\hline Site name & $\begin{array}{l}\text { MRDS } \\
\text { Identifier } \\
\text { number }\end{array}$ & $\begin{array}{c}\text { MAS } \\
\text { Identifier } \\
\text { number }\end{array}$ & Latitude & Longitude & County $^{1}$ \\
\hline 1 Boulder Creek placers & W007555 & & 48.6006 & -116.0883 & Boundary \\
\hline 2 Copper Creek & na & 0160210133 & 48.9803 & -116.1728 & Boundary \\
\hline 3 Point Bar Placer & na & 0160210134 & 48.7861 & -116.1533 & Boundary \\
\hline 4 Alva Stout & M056072 & & 48.6494 & -118.7744 & Ferry \\
\hline 5 Blance & M056073 & & 48.6528 & -118.8058 & Ferry \\
\hline 6 Blue Bar Island & M056062 & & 48.2000 & -118.2003 & Ferry \\
\hline 7 Blue Bar Island Placer & na & 0530190123 & 48.2072 & -118.1994 & Ferry \\
\hline 8 Bridge Creek & M056063 & & 48.2264 & -118.1767 & Ferry \\
\hline 9 Daisy & M056067 & & 48.3897 & -118.1981 & Ferry \\
\hline 10 Dora B Placer & na & 0530190127 & 48.6472 & -118.8153 & Ferry \\
\hline 11 Dova B & M056074 & & 48.6528 & -118.8058 & Ferry \\
\hline 12 Gold Creek & M056077 & & 48.4253 & -118.8450 & Ferry \\
\hline 13 Goosmus Creek Placer & na & 0530190129 & 48.9631 & -118.5806 & Ferry \\
\hline 14 Johnson Placer & M056068 & & 48.2911 & -118.1633 & Ferry \\
\hline 15 Keller Placers & na & 0530190397 & 48.0856 & -118.6903 & Ferry \\
\hline 16 Ninemile & M056070 & & 48.0158 & -118.3972 & Ferry \\
\hline 17 Sanpoint River, West Fla. & M056076 & & 48.4581 & -118.7719 & Ferry \\
\hline 18 Singer Placer & SP00111 & & 48.9961 & -118.5308 & Ferry \\
\hline 19 Stray Dog Placer & M056065 & & 48.2053 & -118.1992 & Ferry \\
\hline 20 Thompson & M056066 & & 48.2189 & -118.1861 & Ferry \\
\hline 21 Turtle Rapids Placer & na & 0530190177 & 48.1783 & -118.2500 & Ferry \\
\hline 22 Ballard Placer & na & 0530470493 & 48.5319 & -119.7450 & Okanogan \\
\hline 23 Cassimer Bar Placer & SP00204 & & 48.0992 & -119.7181 & Okanogan \\
\hline 24 Condon Bar Placer & na & 0530470512 & 48.1100 & -119.3111 & Okanogan \\
\hline 25 Crounce Placer & SP00211 & & 48.3997 & -118.8789 & Okanogan \\
\hline 26 Cuba Line Placer & M056821 & & 48.9967 & -119.1053 & Okanogan \\
\hline 27 Dan Mooney Placer & na & 0530470513 & 48.9606 & -119.0406 & Okanogan \\
\hline 28 Davey Placer & na & 0530470514 & 48.9600 & -119.0408 & Okanogan \\
\hline 29 Deadman Creek Placer & na & 0530470497 & 48.9167 & -119.0550 & Okanogan \\
\hline 30 Fourth of July Creek Placer & na & 0530470498 & 48.9167 & -119.0558 & Okanogan \\
\hline 31 Gold Bar Placer & na & 0530470508 & 48.1053 & -119.2664 & Okanogan \\
\hline 32 Hopkins Placer & na & 0530470499 & 48.1133 & -119.2311 & Okanogan \\
\hline 33 Mary Ann Creek Placer & SP00250 & & 48.9403 & -119.0517 & Okanogan \\
\hline 34 Meadows Placer & na & 0530470501 & 48.6550 & -119.8528 & Okanogan \\
\hline 35 Murray Placer & M056823 & & 48.2000 & -119.2544 & Okanogan \\
\hline 36 Nespelem Bar Placer & na & 0530470502 & 48.1361 & -119.0539 & Okanogan \\
\hline
\end{tabular}




\section{B. Placer sites (cont.)}

\begin{tabular}{|c|c|c|c|c|c|}
\hline 37 Nugget Placer & na & 0530470503 & 48.4100 & -118.9039 & Okanogan \\
\hline 38 Rich Bar Placer & na & 0530470045 & 48.9822 & -119.5364 & Okanogan \\
\hline 39 Shotwell Placer & SP00284 & & 48.0342 & -119.6828 & Okanogan \\
\hline 40 Similkameen Falls Placer & na & 0530470505 & 48.9703 & -119.5017 & Okanogan \\
\hline 41 Similkameen Placers & na & 0530470506 & 48.9806 & -119.5492 & Okanogan \\
\hline 42 Walker Placer & SP00299 & & 48.9689 & -119.1144 & Okanogan \\
\hline 43 Browns Lake Placer & M025803 & & 48.4392 & -117.1828 & Pend Oreille \\
\hline 44 Harvey Bar Placer & M025804 & & 48.9439 & -117.3300 & Pend Oreille \\
\hline 45 Schierding Placer & M025805 & & 48.9881 & -117.3447 & Pend Oreille \\
\hline 46 Schultz Placer & na & 0530510304 & 48.8597 & -117.4111 & Pend Oreille \\
\hline 47 Sullivan Creek Placer & na & 0530510305 & 48.8383 & -117.2653 & Pend Oreille \\
\hline 48 Ambrose Mining & na & 0530650884 & 48.9611 & -117.8500 & Stevens \\
\hline 49 Blue Bar & M056523 & & 48.1714 & -118.1875 & Stevens \\
\hline 50 Blue Bar Placer & na & 0530650172 & 48.1700 & -118.1833 & Stevens \\
\hline 51 Bossburg Placer & M056520 & & 48.7564 & -118.0475 & Stevens \\
\hline 52 China Bend Placer & na & 0530650173 & 48.8006 & -118.0192 & Stevens \\
\hline 53 Collins & M056525 & & 48.3883 & -118.1697 & Stevens \\
\hline 54 Evans Placer & na & 0530650174 & 48.9350 & -117.7631 & Stevens \\
\hline 55 Gibson Bara & M056524 & & 48.0214 & -118.3919 & Stevens \\
\hline 56 Holsten & M056522 & & 48.5000 & -118.1750 & Stevens \\
\hline 57 Marcus Placer & M056518 & & 48.6656 & -118.0675 & Stevens \\
\hline 58 Meyers Falls & M056515 & & 48.5936 & -118.0647 & Stevens \\
\hline 59 Nigger Creek Bar Placer & na & 0530650179 & 48.9403 & -117.7656 & Stevens \\
\hline 60 Ninemile Bar & M056519 & & 48.7956 & -118.0036 & Stevens \\
\hline 61 Nobles Placer & na & 0530650182 & 48.8472 & -117.9117 & Stevens \\
\hline 62 Orient & M056521 & & 48.8611 & -118.1997 & Stevens \\
\hline 63 Orient Placer & na & 0530650184 & 48.8606 & -118.0722 & Stevens \\
\hline 64 Reed and Roberts Placer & na & 0530650185 & 48.9544 & -117.7344 & Stevens \\
\hline 65 Sandoz & M056517 & & 48.6964 & -118.0164 & Stevens \\
\hline 66 Stranger Creek & M056069 & & 48.3083 & -118.1478 & Stevens \\
\hline 67 Valbush Bar & M056516 & & 48.7000 & -118.0206 & Stevens \\
\hline
\end{tabular}




\section{Table $2 b-P a t t e r n$ analysis results for lithologic map units}

[lithology units defined in Boleneus and Causey, 2000; (1) Outside - outside the pattern]

Continued from bottom of previous column

\begin{tabular}{|c|c|c|c|c|c|c|c|}
\hline $\begin{array}{c}\text { Formation } \\
\text { symbol }\end{array}$ & $\begin{array}{l}\text { Area, } \\
\mathrm{km}^{2}\end{array}$ & $\begin{array}{c}\text { Number of } \\
\text { training } \\
\text { sites }\end{array}$ & $\operatorname{Rank}(1)$ & $\begin{array}{c}\text { Formation } \\
\text { symbol }\end{array}$ & $\begin{array}{c}\text { Area, } \\
\mathrm{km}^{2}\end{array}$ & $\begin{array}{c}\text { Number of } \\
\text { training } \\
\text { sites }\end{array}$ & Rank (1) \\
\hline $\mathrm{bx}$ & 6.4 & 0 & Outside & Ols & 117.3 & 0 & Outside \\
\hline Ccbl & 1.8 & 0 & Outside & Omd & 109.3 & 0 & Outside \\
\hline Ccbm & 22.0 & 0 & Outside & Oml & 195.1 & 0 & Outside \\
\hline CDcb & 2.8 & 0 & Outside & pChm & 166.7 & 0 & Outside \\
\hline $\mathrm{CDmm}$ & 110.2 & 0 & Outside & pJmm & 3.6 & 0 & Outside \\
\hline $\mathrm{CDmv}$ & 4.8 & 0 & Outside & pJmsg & 62.6 & 0 & Outside \\
\hline COcb & 2.3 & 0 & Outside & pJmx & 99.9 & 0 & Outside \\
\hline COcg & 6.7 & 0 & Outside & pJtz & 1.8 & 0 & Outside \\
\hline $\mathrm{COm}$ & 62.7 & 0 & Outside & pKma & 22.4 & 0 & Outside \\
\hline $\mathrm{COmv}$ & 29.3 & 0 & Outside & pKmog & 54.7 & 0 & Outside \\
\hline Cphm & 327.9 & 0 & Outside & $\mathrm{pKmu}$ & 21.5 & 0 & Outside \\
\hline Czq & 364.5 & 0 & Outside & $\mathrm{pKmx}$ & 0.9 & 0 & Outside \\
\hline Dcb & 0.5 & 0 & Outside & PLMcg & 9.3 & 0 & Outside \\
\hline Ecg & 27.6 & 0 & Outside & PMmc & 32.2 & 0 & Outside \\
\hline $\mathrm{Ei}$ & 1.6 & 0 & Outside & PMms & 300.4 & 0 & Outside \\
\hline Eia & 13.5 & 0 & Outside & PMmv & 2.3 & 0 & Outside \\
\hline Eib & 9.3 & 0 & Outside & pTma & 31.1 & 0 & Outside \\
\hline Eig & 74.8 & 0 & Outside & pTmbg & 377.2 & 0 & Outside \\
\hline Eigd & 43.2 & 0 & Outside & pTmgg & 172.7 & 0 & Outside \\
\hline Eik & 9.8 & 0 & Outside & pTmi & 4.2 & 0 & Outside \\
\hline Eim & 50.3 & 0 & Outside & pTmn & 38.0 & 0 & Outside \\
\hline Eimd & 198.0 & 0 & Outside & pTmog & 584.9 & 0 & Outside \\
\hline Eiqm & 338.7 & 0 & Outside & pTmpg & 103.8 & 0 & Outside \\
\hline Eir & 0.4 & 0 & Outside & pTmqs & 366.6 & 0 & Outside \\
\hline EPia & 6.2 & 0 & Outside & pTmx & 40.5 & 0 & Outside \\
\hline EPid & 3.1 & 0 & Outside & $\mathrm{PZmc}$ & 4.3 & 0 & Outside \\
\hline EPig & 198.6 & 0 & Outside & PZmd & 2.1 & 0 & Outside \\
\hline EPigb & 330.5 & 0 & Outside & PZmq & 15.4 & 0 & Outside \\
\hline EPigd & 162.0 & 0 & Outside & $\mathrm{PZms}$ & 36.1 & 0 & Outside \\
\hline EPigk & 610.0 & 0 & Outside & PZmu & 10.6 & 0 & Outside \\
\hline EPigm & 330.5 & 0 & Outside & Scg & 2.6 & 0 & Outside \\
\hline EPiqp & 7.3 & 0 & Outside & Smm & 2.2 & 0 & Outside \\
\hline $\mathrm{Et}$ & 45.8 & 0 & Outside & TKia & 23.0 & 0 & Outside \\
\hline Etz & 9.4 & 0 & Outside & TKiaa & 9.8 & 0 & Outside \\
\hline Ev & 2.4 & 0 & Outside & TKigd & 2.8 & 0 & Outside \\
\hline Evcg & 2.5 & 0 & Outside & TKik & 2.5 & 0 & Outside \\
\hline Evcl & 91.2 & 0 & Outside & TRmc & 55.0 & 0 & Outside \\
\hline Evf & 217.6 & 0 & Outside & TRmig & 17.2 & 0 & Outside \\
\hline Evsv & 10.6 & 0 & Outside & TRms & 73.0 & 0 & Outside \\
\hline $\mathrm{Jib}$ & 16.5 & 0 & Outside & $\mathrm{TRmu}$ & 1.3 & 0 & Outside \\
\hline Jik & 6.1 & 0 & Outside & TRmv & 5.7 & 0 & Outside \\
\hline Jiqm & 75.9 & 0 & Outside & TRPMmb & 23.5 & 0 & Outside \\
\hline
\end{tabular}


C. Table $2 \mathrm{~b}$-Pattern analysis results for lithologic map units (cont.)

\begin{tabular}{|c|c|c|c|c|c|c|c|}
\hline $\mathrm{Jmc}$ & 14.1 & 0 & Outside & TRPMmd & 0.9 & 0 & Outside \\
\hline Jmig & 36.1 & 0 & Outside & TRPMms & 41.4 & 0 & Outside \\
\hline $\mathrm{Jmv}$ & 136.2 & 0 & Outside & TRPMmv & 12.4 & 0 & Outside \\
\hline JTigd & 192.6 & 0 & Outside & TRPMu & 5.1 & 0 & Outside \\
\hline JTiqd & 177.3 & 0 & Outside & water & 425.5 & 0 & Outside \\
\hline $\mathrm{Ju}$ & 0.0 & 0 & Outside & Yart & 7.7 & 0 & Outside \\
\hline $\mathrm{Kcg}$ & 9.0 & 0 & Outside & Ybbs & 55.6 & 0 & Outside \\
\hline Kid & 10.7 & 0 & Outside & Ybha & 23.4 & 0 & Outside \\
\hline Kig & 226.6 & 0 & Outside & Ybhq & 17.1 & 0 & Outside \\
\hline Kigd & 1288.9 & 0 & Outside & Ybi & 11.3 & 0 & Outside \\
\hline Kihgd & 38.1 & 0 & Outside & Ybms & 3.3 & 0 & Outside \\
\hline Kim & 221.3 & 0 & Outside & Ybps & 222.5 & 0 & Outside \\
\hline Kiqm & 186.1 & 0 & Outside & Ybrq & 78.1 & 0 & Outside \\
\hline KJid & 17.1 & 0 & Outside & Ybsrs & 37.7 & 0 & Outside \\
\hline KJigb & 2.1 & 0 & Outside & Ybss & 23.6 & 0 & Outside \\
\hline KJigd & 147.6 & 0 & Outside & Ybwq & 57.2 & 0 & Outside \\
\hline KJik & 3.0 & 0 & Outside & Ybwua & 29.6 & 0 & Outside \\
\hline KJmgg & 45.3 & 0 & Outside & Yed & 29.7 & 0 & Outside \\
\hline KJmig & 392.2 & 0 & Outside & Ymcs & 40.5 & 0 & Outside \\
\hline KJmix & 262.9 & 0 & Outside & Yprc & 16.6 & 0 & Outside \\
\hline KJmm & 18.7 & 0 & Outside & Ypres & 21.1 & 0 & Outside \\
\hline KJmo & 136.6 & 0 & Outside & Yprl & 11.6 & 0 & Outside \\
\hline KJmog & 55.0 & 0 & Outside & Yprq & 9.5 & 0 & Outside \\
\hline KJmqd & 5.2 & 0 & Outside & Ypru & 18.5 & 0 & Outside \\
\hline $\mathrm{Mc}$ & 5.6 & 0 & Outside & Ysd & 16.6 & 0 & Outside \\
\hline MDcb & 4.4 & 0 & Outside & Ytar & 98.3 & 0 & Outside \\
\hline Mvg & 158.5 & 0 & Outside & Zhcg & 15.3 & 0 & Outside \\
\hline Mvw & 158.8 & 0 & Outside & Zhmv & 67.6 & 0 & Outside \\
\hline MZia & 3.7 & 0 & Outside & $\mathrm{Zi}$ & 5.1 & 0 & Outside \\
\hline MZid & 2.7 & 0 & Outside & Zlmv & 63.5 & 0 & Outside \\
\hline MZmg & 1.7 & 0 & Outside & Zmlv & 75.7 & 0 & Outside \\
\hline MZmgg & 33.1 & 0 & Outside & $\mathrm{Zmmm}$ & 3.3 & 0 & Outside \\
\hline MZmqd & 26.9 & 0 & Outside & Zscg & 97.1 & 0 & Outside \\
\hline Mzu & 5.8 & 0 & Outside & Zsl & 0.8 & 0 & Outside \\
\hline Occ & 66.0 & 0 & Outside & Zsp & 28.2 & 0 & Outside \\
\hline Ocs & 410.3 & 0 & Outside & Zsq & 2.7 & 0 & Outside \\
\hline Ocv & 40.7 & 0 & Outside & Ztq & 47.3 & 0 & Outside \\
\hline Oig & 1.3 & 0 & Outside & $\mathrm{Zu}$ & 2.7 & 0 & Outside \\
\hline
\end{tabular}

Continued on right column at top of table 


\section{Appendix II. Glossary ${ }^{6}$}

Buffer-A polygon enclosing an area within specified distance from a point, line or polygon. In ArcView/Weights-of-Evidence, buffering is performed using Spatial Analyst so the output is always a grid (raster). The buffering function generates one or more buffers of equal distance from the input features. Input can be either vector or raster data.

Categorical weights calculation (analysis) - Refers to weights calculated for each class in an evidential theme. In ArcView-Weights-of-Evidence, categorical analysis describes one of the tables of weights that can be created using the "Calculate Theme Weights" function, distinguishing it from "Cumulative Weights". Categorical refers to measurements made or labels given at the nominal scale of measurement. Nominal measurements are simply numerical measurements without quantitative context. Numbers assigned arbitrarily to rock types are a common geological example (Bonham-Carter, 1994, p. 41)

Conditional independence - Conditional independence of evidential themes with respect to the training points is assumed for the weights of evidence. The product of area and posterior probability summed over each unique condition is the number of points predicted by the model. A ratio is calculated by dividing the actual number of training points input to the model by this predicted number of points. The ratio will be between 1 and 0 . A value of 1 (never occurs in practice) indicates conditional independence among the evidential themes used in the model. Values less than 1 indicates a conditional independence problem although the values $>0.5$ may produce reasonable results. See Bonham-Carter (1994) for rigorous discussion of conditional independence.

Contrast-Difference between weights, $\mathrm{W}^{+}$and $\mathrm{W}^{-}$. Difference between the natural logs of conditional odds that $\mathrm{A}$ and $\mathrm{B}$ occur together and the natural log of the conditional odds that $\mathrm{A}$ and $\mathrm{B}$ do not occur together. $C=\ln \left(\operatorname{Odds}\left\{B \mid A^{+}\right\}\right)-\ln \left(\operatorname{Odds}\left\{B \mid A^{-}\right\}\right)$; where $\mathrm{A}=$ evidence layer; $\mathrm{B}$ $=$ training set. A rule-of-thumb for interpreting contrast values for predictor themes is given below:

\begin{tabular}{ll}
\hline If contrast value is: & Level of prediction is: \\
\hline $0-0.5$ & Mildly \\
$0.5-1$ & Moderately \\
$1-2$ & Strongly \\
$>2$ & Extremely \\
\hline
\end{tabular}

The contrast values of 1 and 2, respectively, approximate probability values of 0.75 and 0.88 . The level of significance of contrast values is determined by the studentized contrast value. See Bonham-Carter (1994, p. 323) for discussion. This is the contrast divided by its standard deviation. The approach used here is that a studentized contrast value of 2.0 is approximately equivalent to a $98 \%$ level of confidence.

The relationship of probability, odds and weight (natural logarithm of odds) are shown in the table (below).

\begin{tabular}{ccc}
\hline Probability $(P)$ & Odds & Weight $^{(I)}$ \\
\hline 0.1 & $1 / 9$ & -2.2 \\
0.5 & $1 / 1$ (even) & 0.0 \\
0.75 & $3 / 1$ & 1.1 \\
0.88 & $88 / 12$ & 2.0 \\
0.99 & $99 / 1$ & 4.6 \\
\hline
\end{tabular}

(1) also known as logit

\footnotetext{
${ }^{6}$ From user guide (Kemp and others, 1999). For additional explanation, see also Bonham-Carter (1994).
} 
Cumulative weights (analysis) — Refers to weights calculated for cumulative number of points and areas for classes of ordered data. Cumulative weights calculated from either highest to lowest (descending) or lowest to highest (ascending) class, can be calculated for a single evidential theme in the "Calculate Theme Weights" function. Refers to a method of calculating weights for cumulative distances, and examining the weights and contrasts at successive cumulative distance intervals from a source (line, point, or polygon). Calculating cumulative weights can be useful in reducing noise from variation that occurs in categorical weights, making it easier to determine the optimum cut-off points for generalization of data.

Evidence (predictor) theme - A spatial data set used as evidence for prediction of training points (e.g. mineral occurrences). ArcView-WofE is able to use polygon features themes (shapefiles or coverages) or integer grid themes (grid format) as evidential themes.

Pattern generalization - In ArcView/WofE, the product resulting from reclassification of the thematic information of an evidential theme by classifying (grouping) existing classes in the theme attribute table to fewer classes in a new field.

Negative weight, $\mathbf{W}^{-}$- Natural logarithm of the quantity: Odds that the evidence layer and training set do not occur together divided by the odds of training set occurring within the study area. $W=\ln \left(\operatorname{Odds}\left\{B \mid A^{-}\right\} / O d d s\{B\}\right)$; where $\mathrm{A}=$ evidence layer; $\mathrm{B}=$ training set

Normalized contrast-Contrast divided by the standard deviation of contrast.

Positive weight, $\mathbf{W}^{+}$-Natural logarithm of the quantity: Odds that the evidence layer and training set occur together divided by the odds of training set occurring within the study area. Difference between the unconditional or prior logit of $\mathrm{A}$ and the posterior logit of A. A logit equals the $\ln$ odds. $W^{+}=\ln \left(\operatorname{Odd}\left\{\left\{B \mid A^{+}\right\} / O d d s\{B\}\right)\right.$; where $\mathrm{A}=$ evidence layer; $\mathrm{B}=$ training set.

Posterior probability-A redistribution of the prior probability based on the weights. See Bonham-Carter (1994) for a rigorous discussion.

Prior probability-Number of points in training set divided by the study area, expressed by the same area unit (cell size).

Response theme - An output map that expresses the probability that a unit area contains a training point, estimated by combining the weights of the predictor variable (evidence themes). The theme is bases on a unique conditions grid and its attribute table.

Training set or sites-Point feature theme used in the calculation of weights. The set of spatial objects whose locations are to be predicted. In mineral exploration, these are the sites of known mineral deposits. Points are either present or absent. Size or other attributes of these points are not modeled (Raines, Bonham-Carter, and Kemp, 2000).

Weights calculation example--Weights calculations are carried out by two different procedures, by categorical or by cumulative calculations. The categorical method is used where data occurring that occur in categories being measured at not related or categories are mutually exclusive. When number or symbols are used to identify the groups to which various objects belong, the numbers or symbols are referred to as belonging to a nominal or classificatory scale of measurement (Siegel, 1956, p. 22). The categories Yes and No are an example. The lithologic units of a geologic map are another example. The positive weight equals the natural logarithm of the odds that the evidence layer and the training set occur together divided by the odds of the training set occurring in the study area. The negative weight equals the natural logarithm of the odds that the evidence layer and the training set do not occur together divided by the odds of the training set occurring within the study area. The data needed to do the calculation is gathered in a 
two, 2-by-n contingency tables (where $n=$ number of lithologic units on the map) for training sites that occur inside each lithologic unit and training sites that occur outside each lithologic unit. The Eck unit in the Klondike Mountain Formation is the example used in the table below (areas are $\mathrm{km}^{2}$ ):

\begin{tabular}{|c|c|c|c|c|c|c|}
\hline \multirow{2}{*}{$\begin{array}{l}\text { Lithologic } \\
\text { unit }\end{array}$} & \multicolumn{2}{|c|}{$\begin{array}{l}\text { Occur inside lithologic } \\
\text { unit }\end{array}$} & \multicolumn{2}{|c|}{$\begin{array}{l}\text { Occur outside lithologic } \\
\text { unit }\end{array}$} & \multicolumn{2}{|c|}{ Total } \\
\hline & Training sites & Area, $\mathrm{km}^{2}$ & Training sites & Area, $\mathrm{km}^{2}$ & Training sites & Area, $\mathrm{km}^{2}$ \\
\hline Eck & 4 & 26.3 & 46 & $23,573.7$ & 50 & 23,600 \\
\hline and so on & & & & & & \\
\hline
\end{tabular}

Take for example, the geologic map unit Eck, the positive weight equals $\ln$ of the number of training sites divided by the area of Eck divided by the prior probability. The prior probability is $50 / 23600$ (the study area is $23600 \mathrm{~km}^{2}$ and a training site is assumed to occupy one $\mathrm{km}^{2}$ ) equals .00212 .

$$
\operatorname{Ln}([4 / 26.3] / 0.00212)=4.273
$$

For Eck, the negative weight equals the ln of the number of training sites outside Eck divided by the area outside Eck.

$$
\operatorname{Ln}([50-4 / 23600-26.3] / 0.00212)=-.08292
$$

The contrast equals the difference between the positive and negative weights

$$
4.273-(-0.08292)=4.359
$$

The cumulative weights calculation is carried out in the same fashion as outlined above. The only exception is the manner of collecting the data for the 2-by-n contingency table. Unlike the data in unrelated categories discussed above, where data are related between categories, the calculation may be carried out on a cumulative weights fashion. In this case a series of buffer bands (buffer widths vary from $100 \mathrm{~m}$ to 1000 widths) are constructed around the features. Using $1000 \mathrm{~m}$ wide bands, calculations are carried out for each band, $1000 \mathrm{~m}, 2000 \mathrm{~m}$ and so on, in a cumulative fashion or beyond the distance needed to capture all training sites within the buffer bands. Calculations outlined above are the same except that the area within the bands and the training sites within them are accumulated for each successive calculation (e.g. 0-1000m, 0$2000 \mathrm{~m}, 0-3000 \mathrm{~m}$...). Example data for a contingency table of sites occurring inside the bands is given below:

\begin{tabular}{llllll}
\hline Buffer & Cumulative & Training sites & Cumulative & Area, $\mathrm{km}^{2}$ & Cumulative \\
\hline $1000 \mathrm{~m}$ & $1-1000 \mathrm{~m}$ & 1 & 1 & 70 & 70 \\
2000 & $0-2000$ & 10 & 11 & 80 & 160 \\
3000 & $0-3000$ & 18 & 29 & 1000 & 260 \\
and so on & & & & & \\
\hline
\end{tabular}

